\title{
In vitro anti-allergic activity of Moringa oleifera Lam. extracts and their isolated compounds
}

Nur Zahirah Abd Rani, Endang Kumolosasi, Malina Jasamai, Jamia Azdina Jamal, Kok Wai Lam and Khairana Husain*

\begin{abstract}
Background: Moringa oleifera Lam. is a commonly used plant in herbal medicine and has various reported bioactivities such as antioxidant, antimicrobial, anticancer and antidiabetes. It is rich in nutrients and polyphenols. The plant also has been traditionally used for alleviating allergic conditions. This study was aimed to examine the anti-allergic activity of $M$. oleifera extracts and its isolated compounds.
\end{abstract}

Method: M. oleifera leaves, seeds and pods were extracted with $80 \%$ of ethanol. Individual compounds were isolated using a column chromatographic technique and elucidated based on the nuclear magnetic resonance (NMR) and electrospray ionisation mass spectrometry (ESIMS) spectral data. The anti-allergic activity of the extracts, isolated compounds and ketotifen fumarate as a positive control was evaluated using rat basophilic leukaemia (RBL$2 \mathrm{H} 3$ ) cells for early and late phases of allergic reactions. The early phase was determined based on the inhibition of beta-hexosaminidase and histamine release; while the late phase was based on the inhibition of interleukin (IL-4) and tumour necrosis factor (TNF-a) release.

Results: Two new compounds; ethyl-(E)-undec-6-enoate (1) and 3,5,6-trihydroxy-2-(2,3,4,5,6-pentahydroxyphenyl)4H-chromen-4-one (2) together with six known compounds; quercetin (3), kaempferol (4), $\beta$-sitosterol-3-O-glucoside (5), oleic acid (6), glucomoringin (7), 2,3,4-trihydroxybenzaldehyde (8) and stigmasterol (9) were isolated from $M$. oleifera extracts. All extracts and the isolated compounds inhibited mast cell degranulation by inhibiting betahexosaminidase and histamine release, as well as the release of IL-4 and TNF- $a$ at varying levels compared with ketotifen fumarate.

Conclusion: The study suggested that M. oleifera and its isolated compounds potentially have an anti-allergic activity by inhibiting both early and late phases of allergic reactions.

Keywords: Moringa oleifera, Anti-allergic, Isolation, RBL-2H3, Histamine, Beta-hexosaminidase, IL-4, TNF- a, New compound

\section{Background}

Moringa oleifera Lam. (M. oleifera) is well known for its nutritional and medicinal values [1]. It is mainly cultivated in the tropical and subtropical continents due to its high tolerance to extreme weather and as a nutritional source [2-4]. The plant is also commonly known as kelor, drumstick tree, horseradish tree, marunggay and Sajna $[1,5]$.

\footnotetext{
* Correspondence: khairana@ukm.edu.my

Drug and Herbal Research Centre, Faculty of Pharmacy, Universiti

Kebangsaan Malaysia, Jalan Raja Muda Abdul Aziz, 50300 Kuala Lumpur, Malaysia
}

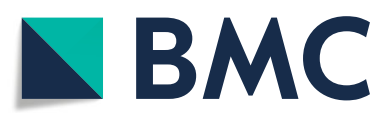

(c) The Author(s). 2019 Open Access This article is distributed under the terms of the Creative Commons Attribution 4.0 International License (http://creativecommons.org/licenses/by/4.0/), which permits unrestricted use, distribution, and

reproduction in any medium, provided you give appropriate credit to the original author(s) and the source, provide a link to the Creative Commons license, and indicate if changes were made. The Creative Commons Public Domain Dedication waiver (http://creativecommons.org/publicdomain/zero/1.0/) applies to the data made available in this article, unless otherwise stated. more vitamin $C$ than oranges, four times more vitamin A than carrots, four times more calcium than milk, two times more protein than yogurt and three times more potassium than bananas [6]. Its immature pods, flowers and leaves contain high percentage of essential amino acids [7]. The whole plant has high content of unsaturated and essential fatty acid such as linolenic acid, linoleic acid and oleic acid; as well as micronutrients such as iron, zinc, vitamin A, calcium and $\beta$-carotene [8]. The ability of the nutritious plant to rapidly grow in harsh climates with high yield helps in combatting severe 
malnutrition of the populations in the subtropical and tropical regions [9].

M. oleifera also contains high content of polyphenols that contributes to its high total antioxidant capacity and could be medicinally useful for diseases such as cancer, hypertension and hyperglycaemia $[8,10]$. The plant has been reported to have antimicrobial activity against waterborne [11], oral [12] and coliform [13] bacteria, as well as dermatophytes [14]. It has anti-diabetic and antiinflammatory activities that could be associated with high isothiocyanates content [15-17]. Its polyphenols such as chlorogenic acid, vicenin-2 and quercetin were also found to contribute to the wound healing activity [18].

Allergic reaction cases are increasing by years. The reactions can be as mild as a rash and as severe as an anaphylactic shock that can lead to death. Subsequent exposure of allergens will trigger mast cell degranulation, releasing mediators that exhibit allergic symptoms. Early phase of an allergic reaction usually occurs minutes after sensitisation, triggering the release of histamine, that will induce bronchoconstriction, vasodilation and vascular permeability [19]. Meanwhile, the late phase of an allergic reaction occurring hours after sensitisation will trigger the release of cytokines such as IL-4, IL-5, IL-9, IL13 , TNF- $\alpha$ and IFN- $\gamma$ that will recruit inflammatory cells and further bring about mast cell degranulation.

Ayurvedic practitioners have been using $M$. oleifera to alleviate allergic conditions but scientific evidences are still lacking [20]. Due to the high content of flavonoids, the plant could be associated with the anti-allergic activity via inhibition of histamine and IL-4 release $[10,21]$. In this study, the anti-allergic activity of $M$. oleifera extracts from various plant parts and its isolated compounds was evaluated using basophil cells to determine the inhibition of mast cell degranulation and cytokines production.

\section{Methods}

\section{Materials and equipment}

Pre-coated aluminium plate of thin layer chromatography (TLC) with silica gel $60 \mathrm{GF} 254$ of $20 \times 20 \mathrm{~cm}$ dimension (Merck, Darmstadt, Germany) was used to visualize separated spots of compounds upon chromatographic development under ultraviolet light $\left(\lambda_{254}, \lambda_{366}\right.$, model UVGL-58). The compounds isolation process was conducted using a column chromatographic technique with silica gel 60 (230-400 mesh ASTM) (Merck, Darmstadt, Germany) and Sephadex LH20 (GE Healthcare, Uppsala, Sweden) as the stationary phases. Chemical structures of the compounds were elucidated using a nuclear magnetic resonance (NMR) spectrometer $\left({ }^{1} \mathrm{H}\right.$ NMR $600 \mathrm{MHz}$ and ${ }^{13} \mathrm{C}$ NMR $151 \mathrm{MHz}$, Cryoprobe, Bruker, Basel, Switzerland). Mass of the compounds was analysed using a high-resolution electrospray ionization mass spectrometer (HRESIMS) (Micro TOF-Q, Bruker, Basel,
Switzerland). A 24 well-plate, a 96 well-plate and a $75 \mathrm{~cm}^{2}$ cell culture flask were obtained from NEST, China. An incubator (IR 230 Forma, Thermo Scientific, Massachusetts, USA) and an ELISA microplate reader (Tecan Infinite M200 Pro, Mannedorf, Switzerland) were used throughout the bioassays studies.

\section{Chemicals and reagents}

The TLC plate was sprayed with $10 \%$ sulfuric acid and Dragendorff reagents to visualise the separated spots of compounds obtained. Organic solvents used for the isolation of compounds were of analytical grade (Merck, Darmstadt, Germany). Deuterated chloroform $\left(\mathrm{CDCl}_{3}\right)$ and methanol (MeOD) were used in the NMR spectroscopy. Ketotifen fumarate (Abcam, Cambridge, United Kingdom) was used as a positive control for the bioassay experiments. Minimum essential media (MEM) with Earle's salts and $L$-glutamine, foetal bovine serum (FBS) from Biowest (Missouri, USA) and penicillin-streptomycin $(10,000 \mathrm{U} / \mathrm{mL})$ (Gibco, New Hampshire, USA) were used as cell media.

Rat basophilic leukemic (RBL)-2H3 cells were obtained from the Japanese Collection of Research Bioresources Cell Bank (JCRB, Japan). Dimethyl sulfoxide (DMSO) (Merck, New Jersey, USA) was used for dissolving test samples. The concentration of DMSO was kept below $0.25 \%$ as it was reported safe for RBL-2H3 cell [22]. 3-(4, 5-Dimethylthiazol-2-yl)-2,5-diphenyltetrazolium bromide (MTT) (Goldbio Technology, Missouri, USA) was used to determine cell viability. Monoclonal Anti-Dinitrophenyl (DNP) IgE antibody produced in mouse (Sigma-Aldrich, New Hampshire, USA) were used for cell sensitisation. Bovine serum albumin (BSA) solution (Sigma-Aldrich, New Hampshire, USA), dinitrophenyl-bovine serum albumin (DNP-BSA) (Santa Cruz, USA) and $p$-nitrophenyl- $N$ acethyl- $\beta$-D-glucosaminide (Merck, New Jersey, USA) were used for the bioassays. Histamine, TNF- $\alpha$ and IL-4 Elisa kits were obtained from Elabscience, China.

\section{Plant materials}

Leaves, seeds and pods of $M$. oleifera were obtained from Terengganu, Malaysia. The taxonomy of the specimens was confirmed by Dr. Shamsul Khamis, a botanist from Universiti Kebangsaan Malaysia (UKM). The specimens were deposited at the Universiti Kebangsaan Malaysia Herbarium in Bangi with a voucher specimen UKMB40408.

\section{Preparation of extracts and isolation of compounds}

The plant materials were air-dried and ground before the extraction process. The leaves $(848.9 \mathrm{~g})$, seeds $(1999.2 \mathrm{~g})$ and pods $(2000.0 \mathrm{~g})$ were individually macerated with $80 \%$ of ethanol for three days and filtered. The residue was extracted twice. Filtrates of each plant part were collected and evaporated using a rotary evaporator. 
The remaining water content was removed using a freeze-drying technique. The yield of leaf, seed and pod extracts were $42.43 \mathrm{~g}, 65.05 \mathrm{~g}$ and $59.56 \mathrm{~g}$ respectively. The extracts were sequentially fractionated using hexane, ethyl acetate and acetone as eluting solvents with various compositions.

\section{Structural elucidation of isolated compounds Ethyl-(E)-undec-6-enoate (1)}

Elution of the hexane leaf fraction $(18.91 \mathrm{~g})$ with hexaneethyl acetate $(8: 2, \mathrm{v} / \mathrm{v})$ yielded compound $\mathbf{1}$. White amorphous liquid (34.2 mg), TLC: $\mathrm{R}_{\mathrm{f}} 0.83$ (hexane: EtOAc, 8:2), HRESIMS (+ve mode) $m / z: 235.1295[\mathrm{M}+$ $\mathrm{Na}]^{+}$(calculated for $\mathrm{C}_{13} \mathrm{H}_{24} \mathrm{O}_{2}, 212.33 \mathrm{~g} / \mathrm{mol}$ ). ${ }^{1} \mathrm{H}$ NMR $\left(\mathrm{CDCl}_{3}, 600 \mathrm{MHz}\right): \delta_{\mathrm{H}} 0.85(\mathrm{t}, 3 \mathrm{H}, J=7.1 \mathrm{~Hz}, \mathrm{H}-13), 1.25$ (m, 21H, H-1, H-12), 1.32 (m, 21H, H-6), 1.35 (m, 21H, $\mathrm{H}-11), 1.62(\mathrm{~m}, 2 \mathrm{H}, \mathrm{H}-5), 2.02(\mathrm{~m}, 2 \mathrm{H}, \mathrm{H}-10), 2.31(\mathrm{t}$, $2 \mathrm{H}, J=7.7 \mathrm{~Hz}, \mathrm{H}-4), 2.79$ (m, 1H, H-7), 4.15 (q, 2H, J= $7.1 \mathrm{~Hz}, \mathrm{H}-2), 5.4(\mathrm{~m}, 1 \mathrm{H}, \mathrm{H}-8, \mathrm{H}-9) .{ }^{13} \mathrm{C} \mathrm{NMR}\left(\mathrm{CDCl}_{3}\right.$, $150 \mathrm{MHz})$ : $\delta \mathrm{c} 14.3$ (C-1, C-13), 22.8 (C-12), 24.9 (C-6), 29.1 (C-5), 29.7 (C-11), 31.9 (C-10), 35 (C-4, C7), 60.1 (C-2), 130 (C-8, C-9), 174.3 (C-3).

\section{3,5,6-trihydroxy-2-(2,3,4,5,6-pentahydroxyphenyl)-4H- chromen-4-one (2)}

The ethyl acetate leaf fraction (3.38 g) was loaded onto Sephadex LH-20 using methanol-water (1:1, v/v) yielding four fractions. The third fraction was further eluted using Sephadex LH-20 with chloroform-dichloromethanemethanol (4:1:1, v/v) as a mobile phase giving four fractions. The last fraction was further eluted in silica gel column chromatography with ethyl acetate-chloroform (7:3, $\mathrm{v} / \mathrm{v})$ as a mobile phase yielding compound 2. Reddishbrown liquid (3.9 mg), TLC: $\mathrm{R}_{\mathrm{f}} 0.50\left(\mathrm{CHCl}_{3}: \mathrm{MeOH}, 9: 1\right)$, HRESIMS (+ve mode) $m / z: 176.9835[\mathrm{M}+2 \mathrm{H}]^{2+}($ calculated for $\left.\mathrm{C}_{15} \mathrm{H}_{10} \mathrm{O}_{10}, 350.24 \mathrm{~g} / \mathrm{mol}\right) .^{1} \mathrm{H} \mathrm{NMR}\left(\mathrm{CDCl}_{3}, 600\right.$ $\mathrm{MHz}): \delta_{\mathrm{H}} 6.83$ (d, $\left.1 \mathrm{H}, J=8.6 \mathrm{~Hz}, \mathrm{H}-7\right), 7.89$ (d, $1 \mathrm{H}, J=8.7$ $\mathrm{Hz}, \mathrm{H}-8) .{ }^{13} \mathrm{C} \mathrm{NMR}\left(\mathrm{CDCl}_{3}, 150 \mathrm{MHz}\right): \delta_{\mathrm{c}} 113.3(\mathrm{C}-10)$, 114.3 (C-7), 122.1 (C-1'), 123.0 (C-6), 128.5 (C-3'), 128.5 (C-5'), 131.4 (C-8), 138.5 (C-3), 138.5 (C-4'), 147.5 (C-2'), 147.5 (C-6'), 161.8 (C-9), 162.9 (C-5), 168.9 (C-2), 173.8 (C-4).

\section{Quercetin (3)}

The ethyl acetate leaf fraction $(3.38 \mathrm{~g})$ was loaded onto Sephadex LH-20 using methanol-water (1:1, v/v) yielding four fractions. The fourth fraction was further eluted using Sephadex LH-20 with chloroform-dichloromethanemethanol $(4: 1: 1, \mathrm{v} / \mathrm{v})$ as a mobile phase yielding compound 3. Yellow powder $(5.9 \mathrm{mg})$, m.p $312-314^{\circ} \mathrm{C}$. TLC: $\mathrm{R}_{\mathrm{f}} 0.49$ ( $\mathrm{CHCl}_{3}: \mathrm{MeOH}, 9: 1$ ), HRESIMS (+ve mode) $\mathrm{m} / z: 325.0294$ $[\mathrm{M}+\mathrm{Na}]^{+}$(calculated for $\mathrm{C}_{15} \mathrm{H}_{10} \mathrm{O}_{7}, 302.24 \mathrm{~g} / \mathrm{mol}$ ). ${ }^{1} \mathrm{H}$ NMR $\left(\mathrm{CDCl}_{3}, 600 \mathrm{MHz}\right): \delta_{\mathrm{H}} 6.20(\mathrm{~d}, 1 \mathrm{H}, J=1.8 \mathrm{~Hz}, \mathrm{H}-6), 6.41(\mathrm{~d}$, $1 \mathrm{H}, J=1.8 \mathrm{~Hz}, \mathrm{H}-8), 6.91$ (d, $\left.1 \mathrm{H}, J=8.4 \mathrm{~Hz}, \mathrm{H}-5^{\prime}\right), 7.66$ (dd, $\left.1 \mathrm{H}, J=8.4 \mathrm{~Hz}, \mathrm{H}-6^{\prime}\right), 7.76\left(\mathrm{~d}, 1 \mathrm{H}, J=2.4 \mathrm{~Hz}, \mathrm{H}-2^{\prime}\right) .{ }^{13} \mathrm{C}$ NMR $\left(\mathrm{CDCl}_{3}, 150 \mathrm{MHz}\right): \delta_{\mathrm{c}} 93.3$ (C-8), 98.2 (C-6), 103.3 (C-10), 114.9 (C-2'), 115.1 (C-5'), 120.6 (C-6'), 123.0 (C-1'), 136.1 (C-3), 145.1 (C-3'), 146.9 (C-2), 147.6 (C-4'), 157.1 (C-9), 161.3 (C-5), 164.5 (C-7), 176.2 (C-4).

\section{Kaempferol (4)}

The ethyl acetate leaf fraction (3.38 g) was loaded onto Sephadex LH-20 using methanol-water (1:1, v/v) yielding four fractions. The fourth fraction was further eluted using Sephadex LH-20 with chloroform-dichloromethanemethanol (4:1:1, v/v) as a mobile phase giving another six fractions. The fifth fraction was subjected to silica gel column chromatography using chloroform-methanol $(9: 1, \mathrm{v} / \mathrm{v})$ as a mobile phase to obtain compound 4. Yellow powder (1.3 mg), m.p $276-279^{\circ} \mathrm{C}$. TLC: $\mathrm{R}_{\mathrm{f}} 0.68\left(\mathrm{CHCl}_{3}: \mathrm{MeOH}, 9: 1\right)$, HRESIMS (+ve mode) $m / z: 309.0334[\mathrm{M}+\mathrm{Na}]^{+}$(calculated for $\left.\mathrm{C}_{15} \mathrm{H}_{10} \mathrm{O}_{6}, 286.24 \mathrm{~g} / \mathrm{mol}\right) .{ }^{1} \mathrm{H}$ NMR $\left(\mathrm{CDCl}_{3}, 600 \mathrm{MHz}\right)$ : $\delta_{\mathrm{H}} 6.19$ (s, 1H, H-6), 6.41 (s, 1H, H-8), 6.91 (d, 1H, J=9.0 $\mathrm{Hz}, \mathrm{H}-3^{\prime}$ ), 6.91 (d, 1H, J=9.0 Hz, H-5'), 8.10 (d, 1H, J=8.4 $\left.\mathrm{Hz}, \mathrm{H}-6{ }^{\prime}\right), 8.74$ (s, $\left.1 \mathrm{H}, \mathrm{H}-2^{\prime}\right) .{ }^{13} \mathrm{C}$ NMR $\left(\mathrm{CDCl}_{3}, 150 \mathrm{MHz}\right)$ : $\delta_{\mathrm{c}} 93.1$ (C-8), 97.9 (C-6), 103.2 (C-10), 114.9 (C-3'), 114.9 (C-5'), 122.3 (C-1'), 129.3 (C-2'), 129.3 (C-6'), 135.7 (C-3), 146.7 (C-2), 156.9 (C-9), 159.2 (C-4'), 161.1 (C-5), 164.2 (C7), 176.0 (C-4).

\section{$\beta$-Sitosterol-3-O-glucoside (5)}

The acetone leaf fraction $(0.95 \mathrm{~g})$ was eluted in the silica gel column chromatography using ethyl acetatechloroform $(7: 3, \mathrm{v} / \mathrm{v})$ as a mobile phase to obtain seven fractions. The sixth fraction was separated using ethyl acetate $(8: 2, \mathrm{v} / \mathrm{v})$ yielding four fractions. The fourth fraction was then purified using chloroform-methanol (9:1, $\mathrm{v} / \mathrm{v})$ to give compound 5 . White powder $(8.5 \mathrm{mg})$, m.p 209-211 ${ }^{\circ} \mathrm{C}$. TLC: $\mathrm{R}_{\mathrm{f}} 0.67\left(\mathrm{CHCl}_{3}: \mathrm{MeOH}, 9: 1\right)$, HRESIMS (+ve mode) $m / z: 599.4190[\mathrm{M}+\mathrm{Na}]^{+}$(calculated for $\left.\mathrm{C}_{35} \mathrm{H}_{60} \mathrm{O}_{6}, 576.86 \mathrm{~g} / \mathrm{mol}\right) .{ }^{1} \mathrm{H}$ NMR $\left(\mathrm{CDCl}_{3}, 600\right.$ $\mathrm{MHz}): \delta_{\mathrm{H}} 0.68$ (s, 3H, H-18), 0.83 (m, 7H, H-9), $0.83(\mathrm{~m}$, 7H, H-14), 0.83 (m, 7H, H-24), 0.83 (m, 7H, H-29), 0.92 (d, 4H, $J=6.6 \mathrm{~Hz}, \mathrm{H}-21), 0.92(\mathrm{~d}, 4 \mathrm{H}, J=6.6 \mathrm{~Hz}, \mathrm{H}-26)$, 0.92 (d, 4H, J=6.6 Hz, H-27), 0.96 (s, 6H, H-19), 1.00 (m, 6H, H-1), 1.00 (m, 6H, H-15), 1.17 (m, 5H, H-12), 1.17 (m, 5H, H-17), 1.25 (m, 4H, H-22), 1.25 (m, 4H, H23), 1.25 (m, 4H, H-28), 1.37 (m, 6H, H-8), $1.38(\mathrm{~m}, 6 \mathrm{H}$, $\mathrm{H}-20), 1.42$ (m, 6H, H-11), 1.52 (m, 5H, H-2), 1.52 (m, 5H, H-15), 1.53 (m, 5H, H-12), 1.65 (m, 3H, H-7), 1.65 (m, 3H, H-25), 1.82 (m, 4H, H-16), 1.95 (m, 4H, H-7), $1.98(\mathrm{~m}, 4 \mathrm{H}, \mathrm{H}-4), 2.63$ (m, 1H, H-3), 2.90 (m, 2H, H$\left.2^{\prime}\right), 3.00\left(\mathrm{td}, 2 \mathrm{H}, J=5.2 \mathrm{~Hz}, \mathrm{H}-4^{\prime}\right), 3.08(\mathrm{dd}, 2 \mathrm{H}, J=2 \mathrm{~Hz}$, $\left.\mathrm{H}-5^{\prime}\right), 3.12\left(\mathrm{td}, 2 \mathrm{H}, J=4.8 \mathrm{~Hz}, \mathrm{H}-3^{\prime}\right), 3.48$ (m, 2H, H$\left.2^{\prime}(\mathrm{OH})\right), 3.48\left(\mathrm{~m}, 2 \mathrm{H}, \mathrm{H}-3^{\prime}(\mathrm{OH})\right), 3.48(\mathrm{~m}, 2 \mathrm{H}, \mathrm{H}-$ $\left.4^{\prime}(\mathrm{OH})\right), 3.68\left(\mathrm{~m}, 2 \mathrm{H}, \mathrm{H}-6^{\prime}(\mathrm{OH})\right), 4.25(\mathrm{~d}, 1 \mathrm{H}, J=7.8 \mathrm{~Hz}$, H-6'), 4.45 (d, 1H, J=5.8 Hz, H-6'), 4.91 (d, 3H, J=6.1 $\left.\mathrm{Hz}, \mathrm{H}-1^{\prime}\right), 5.35$ (m, 1H, H-6). ${ }^{13} \mathrm{C} \mathrm{NMR}\left(\mathrm{CDCl}_{3}, 150\right.$ 
$\mathrm{MHz}): \delta_{\mathrm{c}} 12.2$ (C-18), 12.3 (C-29), 19.1 (C-21), 19.4 (C27), 19.6 (C-19), 20.2 (C-26), 23.1 (C-28), 24.3 (C-15), 25.9 (C-23), 28.3 (C-16), 29.1 (C-25), 29.7 (C-2), 31.8 (C7), 31.8 (C-8), 31.8 (C-22), 36.0 (C-10), 36.0 (C-20), 36.7 (C-1), 37.3 (C-12), 38.8 (C-4), 42.3 (C-13), 45.6 (C-24), 50.0 (C-9), 55.9 (C-17), 56.6 (C-14), 61.6 (C-6'), 70.6 (C4'), 73.9 (C-2'), 77.2 (C-5'), 77.3 (C-3), 77.3 (C-3'), 101.2 (C-1'), 121.7 (C-6), 140.9 (C-5).

\section{Oleic acid (6)}

The ethyl acetate seed fraction $(2.10 \mathrm{~g})$ was eluted in the silica gel column chromatography using hexane-ethyl acetate $(7: 3, v / v)$ as a mobile phase yielding three fractions. The second fraction was further eluted using hexane-ethyl acetate $(8: 2, \mathrm{v} / \mathrm{v})$ yielding compound $\mathbf{6}$. White amorphous liquid (24.5 mg), TLC: $\mathrm{R}_{\mathrm{f}} 0.74$ (hexane: EtOAc, 7:3), HRESIMS (+ve mode) $m / z: 603.4867[2 \mathrm{M}+\mathrm{K}]^{+}$(calculated for $\left.\mathrm{C}_{18} \mathrm{H}_{34} \mathrm{O}_{2}, 282.47 \mathrm{~g} / \mathrm{mol}\right) .{ }^{1} \mathrm{H}$ NMR $\left(\mathrm{CDCl}_{3}, 600 \mathrm{MHz}\right): \delta_{\mathrm{H}}$ 0.90 (t, 3H, $J=7.2 \mathrm{~Hz}, \mathrm{H}-18), 1.30$ (m, 20H, H-4, H-5, H-6, H-7, H-12, H-13, H-14, H-15, H-16, H-17), 1.65 (m, 2H, $\mathrm{H}-3), 2.03$ (m, 1H, H-8), 2.03 (m, 1H, H-11), 2.37 (t, 2H, $J=7.2 \mathrm{~Hz}, \mathrm{H}-2), 5.37$ (m, 1H, H-9), 5.37 (m, $1 \mathrm{H}, \mathrm{H}-9) .{ }^{13} \mathrm{C}$ NMR $\left(\mathrm{CDCl}_{3}, 150 \mathrm{MHz}\right): \delta_{\mathrm{c}} 14.1(\mathrm{C}-18), 22.7(\mathrm{C}-17), 24.7$ (C-3), 27.2 (C-8), 27.2 (C-11), 29.0 (C-4), 29.0 (C-5), 29.1 (C-14), 29.1 (C-15), 29.4 (C-13), 29.5 (C-6), 29.7 (C-12), 29.8 (C-7), 31.9 (C-16), 34.3 (C-2), 129.8 (C-10), 130.0 (C9), $179.8(\mathrm{C}-1)$.

\section{Glucomoringin (7)}

The acetone seed fraction $(2.21 \mathrm{~g})$ was eluted in the silica gel column chromatography using chloroform-methanol $(9: 1, \mathrm{v} / \mathrm{v})$ as a mobile phase yielding five fractions. The fourth fraction was eluted using the same mobile phase to obtain compound 7. Yellow liquid $(28.1 \mathrm{mg})$, TLC: $\mathrm{R}_{\mathrm{f}}$ $0.36\left(\mathrm{CHCl}_{3}: \mathrm{MeOH}, 9: 1\right)$, HRESIMS (+ve mode) $\mathrm{m} / z$ : $572.3460[\mathrm{M}+\mathrm{H}]^{+}$(calculated for $\mathrm{C}_{20} \mathrm{H}_{29} \mathrm{NO}_{14} \mathrm{~S}_{2}$, $571.57 \mathrm{~g} / \mathrm{mol}) .{ }^{1} \mathrm{H}$ NMR $\left(\mathrm{CDCl}_{3}, 600 \mathrm{MHz}\right): \delta_{\mathrm{H}} 1.23(\mathrm{q}$, $\left.4 \mathrm{H}, J=4.8 \mathrm{~Hz}, \mathrm{H}-6^{\prime \prime}\right), 3.20$ (m, H-6'), 3.49 (m, H-4"), $3.64\left(\mathrm{~m}, 1 \mathrm{H}, \mathrm{H}-5^{\prime \prime}\right), 3.83$ (s, 1H, H-7), $3.86(\mathrm{dt}, 1 \mathrm{H}, J=$ 1.8, $\left.8.7 \mathrm{~Hz}, \mathrm{H}-3^{\prime \prime}\right), 4.03$ (m, 1H, H-2"), 4.10 (m, H-5'), $4.23\left(\mathrm{~m}, \mathrm{H}-4^{\prime}\right), 4.34\left(\mathrm{~m}, \mathrm{H}-3^{\prime}\right), 4.47(\mathrm{~d}, 1 \mathrm{H}, J=7.2 \mathrm{~Hz}$, $\left.\mathrm{H}-1^{\prime}\right), 4.64\left(\mathrm{~m}, \mathrm{H}-2^{\prime}\right), 5.44(\mathrm{dd}, 1 \mathrm{H}, J=1.8,17.4 \mathrm{~Hz}, \mathrm{H}-$ $\left.1^{\prime}\right), 7.02(\mathrm{~d}, 1 \mathrm{H}, J=4.8 \mathrm{~Hz}, \mathrm{H}-1), 7.09(\mathrm{~d}, 1 \mathrm{H}, J=4.8 \mathrm{~Hz}$, $\mathrm{H}-6), 7.27(\mathrm{~d}, 1 \mathrm{H}, J=3 \mathrm{~Hz}, \mathrm{H}-5), 7.30(\mathrm{~d}, 1 \mathrm{H}, J=8.4 \mathrm{~Hz}$, $\mathrm{H}-3),{ }^{13} \mathrm{C}$ NMR $\left(\mathrm{CDCl}_{3}, 150 \mathrm{MHz}\right): \delta_{\mathrm{c}} 16.7$ (C-6"), 21.2 (C-7), 43.0 (C-4'), 45.5 (C-3'), 47.1 (C-2'), 47.9 (C-6'), 59.8 (C-5'), $65.9\left(\mathrm{C}-1^{\prime}\right), 69.2\left(\mathrm{C}-5^{\prime \prime}\right), 69.3\left(\mathrm{C}-2^{\prime \prime}\right), 70.6$ (C-3"), 72.3 (C-4"), 98.4 (C-1"), 116.1 (C-6), 116.7 (C2), 128.7 (C-3), 129.0 (C-5), 131.7 (C-4), 155.7 (C-1), $156.0(\mathrm{~N})$.

\section{2,3,4-trihydroxybenzaldehyde (8)}

The hexane pod fraction $(19.2 \mathrm{~g})$ was eluted on the silica gel column chromatography using hexane-ethyl acetate
$(8: 2, \mathrm{v} / \mathrm{v})$ as a mobile phase yielding four fractions. The second fraction was further eluted using hexane-ethyl acetate $(9: 1, \mathrm{v} / \mathrm{v})$ giving five fractions. The third fraction was purified using hexane-ethyl acetate $(7: 3, \mathrm{v} / \mathrm{v})$ yielding compound 8. Reddish brown liquid $(1.8 \mathrm{mg})$, TLC: $\mathrm{R}_{\mathrm{f}}$ $0.73\left(\mathrm{CHCl}_{3}: \mathrm{MeOH}, 9: 1\right)$, HRESIMS (+ve mode) $\mathrm{m} /$ $z 193.0489[\mathrm{M}+\mathrm{K}]{ }^{+}\left(\right.$calculated for $\mathrm{C}_{7} \mathrm{H}_{6} \mathrm{O}_{4}, 154.12 \mathrm{~g} /$ mol). ${ }^{1} \mathrm{H}$ NMR $\left(\mathrm{CDCl}_{3}, 600 \mathrm{MHz}\right): \delta_{\mathrm{H}} 6.98(\mathrm{~d}, 1 \mathrm{H}, J=12$ Hz, H-5), 7.83 (d, 1H, J=12 Hz, H-6), 9.89 (s, 1H, H-7). ${ }^{13} \mathrm{C}$ NMR $\left(\mathrm{CDCl}_{3}, 150 \mathrm{MHz}\right): \delta_{\mathrm{c}} 116.0(\mathrm{C}-1), 116.0(\mathrm{C}-$ 5), 130.2 (C-3), 132.4 (C-2), 132.4 (C-4), 161.2 (C-6), $190.8(\mathrm{C}-7)$.

\section{Stigmasterol (9)}

The ethyl acetate pod fraction $(3.0 \mathrm{~g})$ was eluted in the silica gel column chromatography using chloroformethyl acetate $(6: 4, \mathrm{v} / \mathrm{v})$ as a mobile phase eluting fourteen fractions. The second fraction was further subjected to silica gel column chromatography using hexane-ethyl acetate $(8: 2, \mathrm{v} / \mathrm{v})$ to obtain compound 9 . White crystal (28.1 mg), m.p $166-168^{\circ} \mathrm{C}$. TLC: $\mathrm{R}_{\mathrm{f}} 0.39$ (Hexane: EtOAc, 9:1), HR ESIMS (+ve mode) $\mathrm{m} / z: 451.3425[\mathrm{M}+$ $\mathrm{K}]{ }^{+}$(calculated for $\mathrm{C}_{29} \mathrm{H}_{48} \mathrm{O}, 412.70 \mathrm{~g} / \mathrm{mol}$ ). ${ }^{1} \mathrm{H}$ NMR $\left(\mathrm{CDCl}_{3}, 600 \mathrm{MHz}\right): \delta_{\mathrm{H}} 0.70(\mathrm{~s}, 1 \mathrm{H}, \mathrm{H}-18), 0.82(\mathrm{~m}, 3 \mathrm{H}$, $\mathrm{H}-27), 0.83(\mathrm{~m}, 3 \mathrm{H}, \mathrm{H}-29), 0.87$ ( $\mathrm{m}, 3 \mathrm{H}, \mathrm{H}-26), 0.95(\mathrm{~m}$, $3 \mathrm{H}, \mathrm{H}-21), 0.95$ (m, 3H, H-9), 1.02 (s, 3H, H-19), 1.05 (m, 2H, H-14), 1.08 (m, 1H, H-15), $1.12(\mathrm{~m}, 2 \mathrm{H}, \mathrm{H}-1)$, $1.18(\mathrm{~m}, 2 \mathrm{H}, \mathrm{H}-17), 1.28(\mathrm{~s}, 1 \mathrm{H}, \mathrm{H}-12), 1.37(\mathrm{~m}, 2 \mathrm{H}, \mathrm{H}-$ 28), $1.46(\mathrm{~m}, 1 \mathrm{H}, \mathrm{H}-8), 1.48(\mathrm{~m}, 2 \mathrm{H}, \mathrm{H}-11), 1.49(\mathrm{~m}, 1 \mathrm{H}$, $\mathrm{H}-2), 1.52(\mathrm{~m}, 1 \mathrm{H}, \mathrm{H}-24), 1.53(\mathrm{~m}, 1 \mathrm{H}, \mathrm{H}-25), 1.55(\mathrm{~m}$, $1 \mathrm{H}, \mathrm{H}-15), 1.58$ (m, 2H, H-16), $1.71(\mathrm{~m}, 1 \mathrm{H}, \mathrm{H}-2), 1.85$ $(\mathrm{m}, 1 \mathrm{H}, \mathrm{H}-1), 1.88(\mathrm{~m}, 2 \mathrm{H}, \mathrm{H}-7), 1.98(\mathrm{~m}, 1 \mathrm{H}, \mathrm{H}-12)$, $2.25(\mathrm{~m}, 1 \mathrm{H}, \mathrm{H}-20), 2.32(\mathrm{~m}, 1 \mathrm{H}, \mathrm{H}-4), 3.55(\mathrm{~m}, 1 \mathrm{H}, \mathrm{H}-$ 3), $5.04(\mathrm{dd}, 1 \mathrm{H}, J=15 \mathrm{~Hz}, \mathrm{H}-23), 5.16(\mathrm{dd}, 1 \mathrm{H}, J=18$ $\mathrm{Hz}, \mathrm{H}-22), 5.38$ (m, $1 \mathrm{H}, \mathrm{H}-6) .{ }^{13} \mathrm{C}$ NMR $\left(\mathrm{CDCl}_{3}, 150\right.$ $\mathrm{MHz}): \delta_{\mathrm{c}} 12.0$ (C-18), 12.3 (C-29), 19.4 (C-19), 19.9 (C27), 21.1 (C-11), 21.1 (C-26), 21.3 (C-22), 24.3 (C-15), 25.6 (C-28), 29.0 (C-16), 29.8 (C-2), 31.9 (C-7), 31.9 (C8), 31.9 (C-25), 36.5 (C-10), 37.8 (C-1), 39.8 (C-12), 40.0 (C-20), 42.3 (C-13), 44.0 (C-4), 50.1 (C-9), 51.2 (C-24), 55.9 (C-17), 56.8 (C-14), 71.8 (C-3), 121.8 (C-6), 129.3 (C-23), 138.3 (C-22), 140.8 (C-5).

\section{Cell viability assay}

RBL-2H3 cells from the Japanese Collection of Research Bioresources Cell Bank (JCRB, Japan) in enriched media $(100 \mu \mathrm{L})$ were seeded in 96 well plates with cell concentrations of $2.5 \times 10^{5}$ cells $/ \mathrm{mL}$. The cells were incubated for $24 \mathrm{~h}$ at $37^{\circ} \mathrm{C}$ in a humidified incubator $\left(5 \% \mathrm{CO}_{2}\right.$, $95 \%$ air) prior to reconstitution with $100 \mu \mathrm{L}$ of test sample. Then the cells were incubated for another $24 \mathrm{~h}$. $10 \mu \mathrm{L}$ of 3-(4,5-dimethylthiazol-2-yl)-2,5-diphenyltetrazolium bromide (MTT) $(5 \mathrm{mg} / \mathrm{mL}$ in PBS buffer) was added into the mixture and was incubated further for 4 
h. Upon the appearance of purple formazan crystal, the medium was removed and $100 \mu \mathrm{L}$ of DMSO was added. After shaking the plates for $10 \mathrm{~min}$, the absorbance was immediately measured using a microplate reader at 570 $\mathrm{nm}$. Percentage of cell viability was determined as using the formula below, whereby OD means optical density:

$$
\begin{aligned}
& \text { Percentage of cell viability }(\%) \\
& =\frac{\text { OD test sample-OD blank }}{\text { OD control-OD blank }} \times 100
\end{aligned}
$$

\section{Preparation of RBL-2H3 cells for degranulation assessment}

RBL-2H3 cells were cultured in MEM containing 10\% FBS and $1 \%$ penicillin-streptomycin at $37{ }^{\circ} \mathrm{C}$ with $5 \%$ $\mathrm{CO}_{2}$ and $95 \%$ air. The medium was changed every two days and the cells were sub-cultured upon $80 \%$ confluency. Once the cells reached the third passage with stable morphology and growth, the cells were used for the bioassay experiment. Only cells from third to fifth passages were used in this study.

RBL-2H3 cells $\left(2 \times 10^{5} / 400 \mu \mathrm{L}\right)$ in enriched medium were seeded and allowed to adhere onto 24 well plates in the humidified incubator $\left(37^{\circ} \mathrm{C}, 5 \% \mathrm{CO}_{2}, 95 \%\right.$ air $)$ for two hours. The cells were then sensitized with anti-DNP $\operatorname{IgE}(0.45 \mu \mathrm{g} / \mathrm{mL}, 100 \mu \mathrm{L})$ overnight at $37{ }^{\circ} \mathrm{C}$ in $5 \% \mathrm{CO}_{2}$.

\section{Inhibitory effect of beta-hexosaminidase release}

The inhibitory effect of beta-hexosaminidase release from RBL-2H3 cells were measured using the method described by Shahari et al. [23]. The sensitised cells were washed twice with $500 \mu \mathrm{L}$ Siraganian buffer $(119 \mathrm{mM}$ $\mathrm{NaCl}, 5 \mathrm{mM} \mathrm{KCl}, 5.6 \mathrm{mM}$ glucose, $0.4 \mathrm{mM} \mathrm{MgCl} 2,1 \mathrm{mM}$ $\mathrm{CaCl}_{2}, 25 \mathrm{mM}$ piperazine- $N, N^{\prime}$-bis (2-ethanesulfonic acid) (PIPES), $40 \mathrm{mM} \mathrm{NaOH}, 0.1 \% \mathrm{BSA}, \mathrm{pH} 7.2)$ and were reconstituted with $160 \mu \mathrm{L}$ Siraganian buffer. After 10 min of incubation at $37{ }^{\circ} \mathrm{C}$ in $5 \% \mathrm{CO}_{2}$ and $95 \%$ air, the cells were treated with $20 \mu \mathrm{L}$ of test samples (7.81, 15.62 and $31.25 \mu \mathrm{g} / \mathrm{mL}$ ) or $20 \mu \mathrm{L}$ of ketotifen fumarate (7.81, 15.62 and $31.25 \mu \mathrm{g} / \mathrm{mL}$ ) and incubated for another $10 \mathrm{~min}$. Cells degranulation was then stimulated by the addition of $20 \mu \mathrm{L}$ DNP-BSA $(10 \mathrm{mg} / \mathrm{mL})$ allergen for 30 min at $37{ }^{\circ} \mathrm{C}$ in $5 \% \mathrm{CO}_{2}$ and $95 \%$ air. Aliquot of the supernatant $(50 \mu \mathrm{L})$ was then transferred into a 96 well plate and incubated with a substrate $(1 \mu \mathrm{M} p$-nitrophenyl-N-acetyl- $\beta$-D-glucosaminide in $0.1 \mathrm{M}$ citrate buffer, $\mathrm{pH} 4.5$ ) in $1: 1$ ratio at $37^{\circ} \mathrm{C}$ for $1 \mathrm{~h}$. The reaction was quenched with the addition of $200 \mu \mathrm{L}$ of stop solution $\left(0.1 \mathrm{M} \mathrm{Na}_{2} \mathrm{CO}_{3} / \mathrm{NaHCO}_{3}, \mathrm{pH} 10.0\right)$. The absorbance was measured at $405 \mathrm{~nm}$ using a microplate reader. Cells that were exposed to allergen were used as negative control. While cells that did not exposed to allergen were used as normal. The positive control used was ketotifen fumarate. The percentage inhibition was determined using the equation below.

$$
\text { Percentage inhibition }(\%)=\left(1-\frac{\text { OD test sample-OD blank-OD normal }}{\text { OD control-OD normal }}\right) \times 100
$$

\section{Inhibitory effects on histamine and cytokines release}

The inhibitory effects on histamine and cytokines release from RBL-2H3 cells were measured using the previously described methods $[24,25]$. The sensitised cells were washed twice with $500 \mu \mathrm{L}$ enriched medium and were reconstituted with $320 \mu \mathrm{L}$ of enriched medium. After 10 min of incubation, the cells were treated with $40 \mu \mathrm{L}$ of test samples $(7.81,15.62$ and $31.25 \mu \mathrm{g} / \mathrm{mL})$ or $40 \mu \mathrm{L}$ of ketotifen fumarate $(7.81,15.62$ and $31.25 \mu \mathrm{g} / \mathrm{mL})$. For early-phase allergic reaction assay, the cells were stimulated using $40 \mu \mathrm{L}$ of DNP-BSA $(10 \mathrm{mg} / \mathrm{mL})$ allergen for $30 \mathrm{~min}$ at $37^{\circ} \mathrm{C}$ in $5 \% \mathrm{CO}_{2}$ and $95 \%$ air. Aliquot of the supernatant $(50 \mu \mathrm{L})$ was then centrifuged at $1000 \mathrm{x}$ g at $8^{\circ} \mathrm{C}$ for $20 \mathrm{~min}$ and the concentration of histamine released was measured using a Histamine ELISA Kit (Elabscience, China). For late-phase allergic reaction assay, the cells were incubated with $40 \mu \mathrm{L}$ of DNP-BSA $(10 \mathrm{mg} / \mathrm{mL})$ allergen for $4 \mathrm{~h}$ at $37^{\circ} \mathrm{C}$ in $5 \% \mathrm{CO}_{2}$ and $95 \%$ air. The supernatant $(100 \mu \mathrm{L})$ was centrifuged at $1000 \mathrm{x}$ $\mathrm{g}$ at $8{ }^{\circ} \mathrm{C}$ for $20 \mathrm{~min}$ and the concentrations of IL-4 and TNF- $\alpha$ were measured using the respective ELISA kits (Elabscience, China).

\section{Statistical analysis}

The data obtained were reported as mean value \pm standard error of mean (SEM) representing triplicate measurements $(n=3)$. The $\mathrm{IC}_{50}$ values with $95 \%$ confidence intervals were determined using a GraphPad Prism 5

Table $1{ }^{1} \mathrm{H}$ NMR $\left(\mathrm{CDCl}_{3}, 600 \mathrm{MHz}\right)$ and ${ }^{13} \mathrm{C} \mathrm{NMR}\left(\mathrm{CDCl}_{3}, 151\right.$ $\mathrm{MHz}$ ) spectral data of compound 1

\begin{tabular}{llll}
\hline Position & $\delta_{\mathrm{H}}(\mathrm{ppm})$ & $\delta_{\mathrm{C}}(\mathrm{ppm})$ & $\mathrm{HMBC}$ \\
\hline 1 & $1.25(21 \mathrm{H}, \mathrm{m})$ & 14.3 & $\mathrm{C}-2$ \\
2 & $4.15(2 \mathrm{H}, \mathrm{q}, J=7.1 \mathrm{~Hz})$ & 60.1 & $\mathrm{C}-1, \mathrm{C}-3$ \\
3 & - & 174.3 & - \\
4 & $2.31(2 \mathrm{H}, \mathrm{t}, J=7.7 \mathrm{~Hz}))$ & 35.0 & $\mathrm{C}-3, \mathrm{C}-5, \mathrm{C}-6$ \\
5 & $1.60(2 \mathrm{H}, \mathrm{m})$ & 29.1 & $\mathrm{C}-4$ \\
6 & $1.32(21 \mathrm{H}, \mathrm{m})$ & 24.9 & $\mathrm{C}-5$ \\
7 & $2.79(2 \mathrm{H}, \mathrm{m})$ & 35.0 & $\mathrm{C}-8$ \\
8 & $5.41(1 \mathrm{H}, \mathrm{m})$ & 130.0 & $\mathrm{C}-6$ \\
9 & $5.41(1 \mathrm{H}, \mathrm{m})$ & 130.0 & - \\
10 & $2.02(2 \mathrm{H}, \mathrm{m})$ & 31.9 & $\mathrm{C}-11, \mathrm{C}-9$ \\
11 & $1.35(21 \mathrm{H}, \mathrm{m})$ & 29.7 & $\mathrm{C}-13$ \\
12 & $1.25(21 \mathrm{H}, \mathrm{m})$ & 2.8 & $\mathrm{C}-11$ \\
13 & $0.85(4 \mathrm{H}, \mathrm{t}, J=7.1 \mathrm{~Hz}))$ & 14.3 & $\mathrm{C}-11, \mathrm{C}-12$ \\
\hline
\end{tabular}


software. Statistical significance of the data ( $p$-value < $0.05)$ was analysed using one-way ANOVA with GraphPad Prism 5.

\section{Results}

\section{Structure elucidation}

The elution of hexane fraction of $M$. oleifera leaf extract yielded a new compound (compound 1). Compound $\mathbf{1}$ was obtained as white amorphous powder (34.2 mg) with HRESIMS molecular ionisation at $\mathrm{m} / z 235.1295$ corresponding to $[\mathrm{M}+\mathrm{Na}]^{+}$. Based on the value, chemical formula of the compound was deduced as $\mathrm{C}_{13} \mathrm{H}_{24} \mathrm{O}_{2}$ with a molecular weight of $212.33 \mathrm{~g} / \mathrm{mol} .{ }^{1} \mathrm{H}$ and ${ }^{13} \mathrm{C}$ NMR spectral data of the compound (Table 1) suggest the presence of a long chain skeleton with an olefinic signal at $\delta 5.41(\mathrm{H}-8, \mathrm{H}-9)$ and one carbonyl signal at $\delta$ $174.13(\mathrm{C}-3)$. The carbonyl group was positioned at $\mathrm{C}-3$ and the olefin at $\mathrm{H}-8$ as evidenced by the ${ }^{3} J$ correlation measurement between the carbon at $\delta 24.9$ (C-6) and deshielded methylene at $\delta 2.3(\mathrm{H}-4)$, and ${ }^{3} J$ correlation between the carbon at $\delta 24.9(\mathrm{C}-6)$ and olefin at $\delta 5.4$ (H-8) (Fig. 1 and 2). ${ }^{4} J$ correlation between the neighbouring methylene at $\delta 2.02(\mathrm{C}-10)$ of olefin and terminal methyl at $\delta 0.85(\mathrm{H}-13)$ confirmed the position of olefin at C-8 and C-9. Although the olefin resonated as a multiplet, the compound was deduced to be in $E$ conformation which was more stable compared to $Z$ conformation. The spectroscopical data analysis suggest the identity of compound $\mathbf{1}$ as ethyl-(E)-undec-6-enoate.

Compound $\mathbf{2}$ was obtained as reddish-brown crystals $(3.9 \mathrm{mg})$ from the ethyl acetate fraction of $M$. oleifera leaves with HRESIMS molecular ionisation at $\mathrm{m} / \mathrm{z}$ 176.9835 that correspond to $[\mathrm{M}+2 \mathrm{H}]^{2+}$. Based on the MS data, the compound was deduced to have a molecular weight of $350.24 \mathrm{~g} / \mathrm{mol}$ with a molecular formula of $\mathrm{C}_{15} \mathrm{H}_{10} \mathrm{O}_{10}$. From the NMR spectral data (Table 2), compound 2 was found to have a flavanol skeleton with eight hydroxylated carbons, one carbonyl carbon, five quaternary carbons and one methine. Only two doublets signals at $\delta 6.83(\mathrm{H}-7)$ and $\delta 7.89(\mathrm{H}-8)$ were observed on the ${ }^{1} \mathrm{H}$

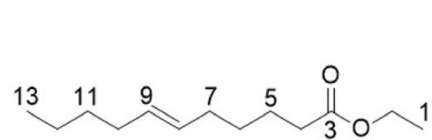

(1)<smiles>O=c1c(O)c(-c2c(O)c(O)c(O)c(O)c2O)oc2ccc(O)c(O)c12</smiles><smiles>O=c1c(O)c(-c2ccc(O)c(O)c2)oc2cc(O)cc(O)c12</smiles>

(3)

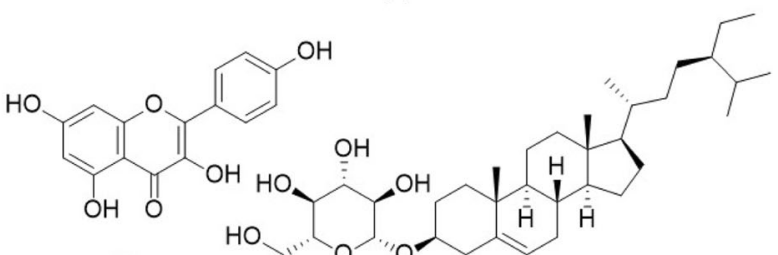

(4)
(5)

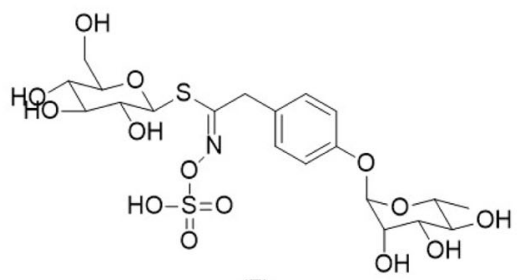

(7)

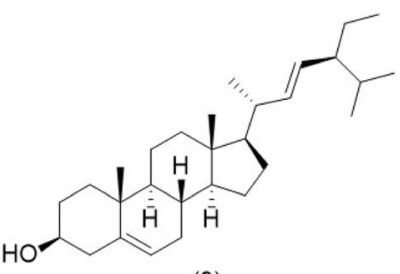

(9)

Fig. 1 Chemical structure of isolated compounds from M. oleifera. Ethyl-(E)-undec-6-enoate (1), 3,5,6-trihydroxy-2-(2,3,4,5,6-pentahydroxyphenyl)4H-chromen-4-one (2), Quercetin (3), Kaempferol (4), B-sitosterol-3-O-glucoside (5), Oleic acid (6), Glucomoringin (7), Stigmasterol (9) 


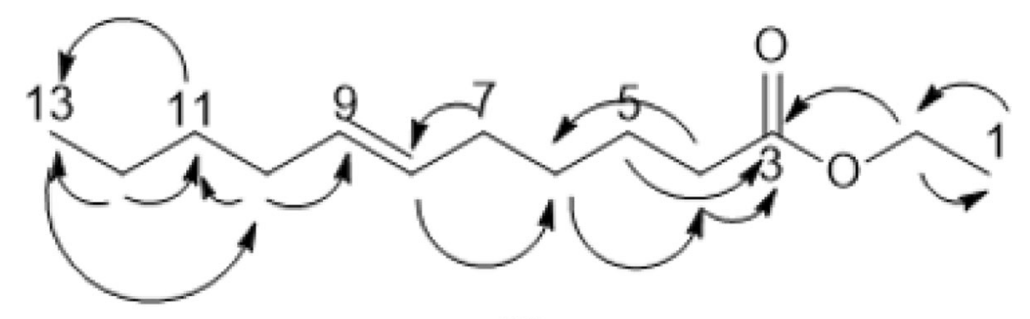

(1)

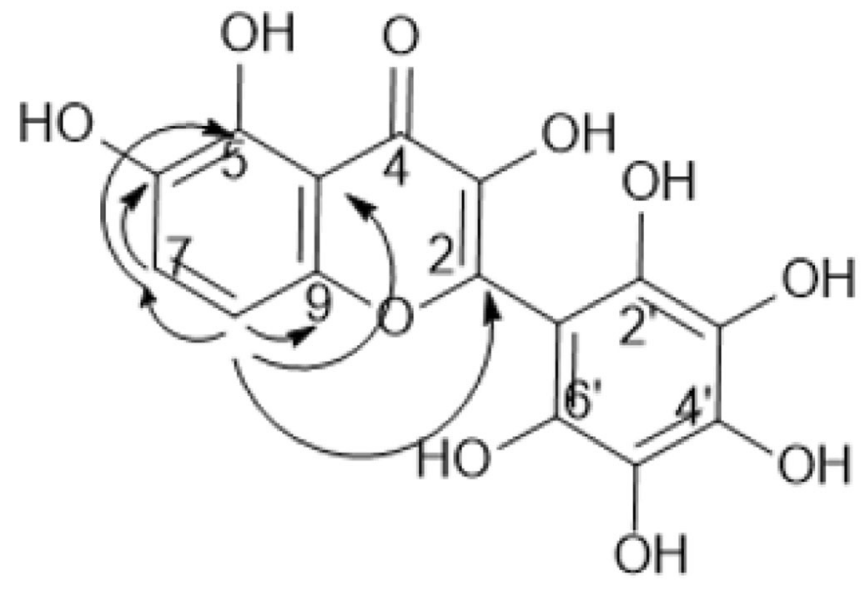

(2)

Fig. $2 \mathrm{HMBC}$ of new isolated compounds (1 and 2)

Table $2{ }^{1} \mathrm{H}$ NMR $\left(\mathrm{CD}_{3} \mathrm{OD}, 600 \mathrm{MHz}\right)$ and ${ }^{13} \mathrm{C} \mathrm{NMR}\left(\mathrm{CD}_{3} \mathrm{OD}, 151 \mathrm{MHz}\right)$ spectral data of compound 2

\begin{tabular}{|c|c|c|c|c|c|}
\hline Position & $\delta_{H}(p p m)$ & $\delta c(p p m)$ & $\cos Y$ & HSQC & HMBC \\
\hline 2 & - & 168.9 & - & - & - \\
\hline 3 & - & 138.5 & - & - & - \\
\hline 4 & - & 173.8 & - & - & - \\
\hline 5 & - & 162.9 & - & - & - \\
\hline 6 & - & 123.0 & - & - & - \\
\hline 7 & $6.83(1 \mathrm{H}, \mathrm{d}, J=8.6 \mathrm{~Hz})$ & 114.3 & $\mathrm{H}-8$ & 114.3 & $C-5, C-6, C-8$ \\
\hline 8 & $7.89(1 \mathrm{H}, \mathrm{d}, J=8.7 \mathrm{~Hz})$ & 131.4 & $\mathrm{H}-7$ & 131.4 & $C-2, C-7, C-9, C-10$ \\
\hline 9 & - & 161.8 & - & - & - \\
\hline 10 & - & 113.3 & - & - & - \\
\hline $1^{\prime}$ & - & 122.1 & - & - & - \\
\hline $2^{\prime}$ & - & 147.5 & - & - & - \\
\hline $3^{\prime}$ & - & 128.5 & - & - & - \\
\hline $4^{\prime}$ & - & 138.5 & - & - & - \\
\hline $5^{\prime}$ & - & 128.5 & - & - & - \\
\hline $6^{\prime}$ & - & 147.5 & - & - & - \\
\hline
\end{tabular}


NMR spectrum. The doublets peaks were ortho-positioned to each other with $J$ coupling value of 8.6 at A ring of the flavanol. ${ }^{3} J$ correlation between the doublets proved the ortho-position of the hydrogen. As no other hydrogen signals were observed, it was deduced that all carbons in ring $\mathrm{B}$ were attached to hydroxyl groups. In addition, ${ }^{3} \mathrm{~J}$ correlation between $\delta 7.89(\mathrm{H}-8)$ and $\delta 168.9(\mathrm{C}-2)$ confirmed the position of the hydrogen at ring $\mathrm{A}$ of the flavanol structure. Based on the spectral data obtained, compound 2 was concluded to be 3,5,6-trihydroxy-2-(2,3, 4,5,6-pentahydroxyphenyl)-4H-chromen-4-one.

Other seven isolated compounds were identified as quercetin (3) [26], kaempferol (4) [27, 28], $\beta$-sitosterol3-O-glucoside (5) [29], oleic acid (6) [30], glucomoringin (7) [31], 2,3,4-trihydroxybenzaldehyde (8) [32] and stigmasterol (9) [33, 34] based on the MS and NMR comparison with the respective literatures (Fig. 1). 2,3,4-trihydroxybenzaldehyde (8) was not included in the bioassay study as the compound was isolated in minute quantity.

\section{Cell viability}

Cell viability assay of $M$. oleifera extracts and the isolated compounds at concentrations of 7.81, 15.62 and $31.25 \mu \mathrm{g} / \mathrm{mL}$ were found not cytotoxic towards the RBL$2 \mathrm{H} 3$ cells as presented in Table 3.

\section{Inhibitory effect of beta-hexosaminidase release}

All extracts (Fig. 3a) and isolated compounds (Fig. 4a) significantly inhibited beta hexosaminidase release in a concentration dependent manner $(7.81,15.62$ and $31.25 \mu \mathrm{g} / \mathrm{mL}$ ) compared with the positive control, ketotifen fumarate $(15.62 \mu \mathrm{g} / \mathrm{mL})$. Amongst the extracts, the leaves exhibited significantly higher activity with $\mathrm{IC}_{50}$ value of $7.17 \pm 1.69 \mu \mathrm{g} / \mathrm{mL}$ than ketotifen fumarate with $\mathrm{IC}_{50}$ value of $15.19 \pm 1.10 \mu \mathrm{g} / \mathrm{mL}$ (Table 4). Four of the isolated compounds from the leaf extract, 3,5,6-
trihydroxy-2-(2,3,4,5,6-pentahydroxyphenyl)-4H-chromen-4-one (2), quercetin (3), kaempferol (4) and $\beta$ sitosterol-3-O-glucoside (5) exhibited significantly higher inhibitory activity than ketotifen fumarate at varying concentrations of 15.62 and $31.25 \mu \mathrm{g} / \mathrm{mL}$, and $p$-values $\left(p<0.01-p<0.001\right.$, Fig. 4a). Based on the $\mathrm{IC}_{50}$ values presented in Table 4, glucomoringin (7) ( $\mathrm{IC}_{50}: 10.43 \pm$ $1.51 \mu \mathrm{M})$ and quercetin $(3)\left(\mathrm{IC}_{50}: 19.07 \pm 7.19 \mu \mathrm{M}\right)$ were found to be significantly more active than ketotifen fumarate $\left(\mathrm{IC}_{50}: 35.70 \pm 2.59 \mu \mathrm{M}\right)$.

Data are presented as mean \pm SEM $(n=3)$ with significance values of $" p<0.05$ and $* * p<0.01$ as compared to positive control.

\section{Inhibitory effect of histamine release}

All extracts significantly inhibited histamine release (Fig. 3b) compared with ketotifen fumarate. All isolated compounds, except $\beta$-sitosterol-3-O-glucoside (5), showed significant inhibitory activity at varying concentrations (Fig. 4b). M. oleifera seed extract had better activity with an $\mathrm{IC}_{50}$ value of $5.97 \pm 0.84 \mu \mathrm{g} / \mathrm{mL}$ than ketotifen fumarate $\left(\mathrm{IC}_{50}: 6.97 \pm 0.04 \mu \mathrm{g} / \mathrm{mL}\right.$, Table 4). Amongst the isolated compounds, ethyl- $(E)$-undec-6-enoate $(\mathbf{1})$, quercetin (3) and kaempferol (4) significantly inhibited histamine release in a concentration dependent manner $(\mathrm{p}<0.01-p<0.001$, Fig. $4 \mathrm{~b})$. Oleic acid (6) and glucomoringin (7) showed significant inhibitory activity at higher concentrations (15.62 and $31.25 \mu \mathrm{g} /$ $\mathrm{mL})$ ( $\mathrm{p}<0.05-\mathrm{p}<0.001$, Fig. $4 \mathrm{~b})$, whereas $3,5,6$-trihydroxy-2-(2,3,4,5,6-pentahydroxyphenyl)- $4 H$-chro-

men-4-one (2) and stigmasterol (9) significantly inhibited only at the highest concentration $(31.25 \mu \mathrm{g} /$ $\mathrm{mL}, \mathrm{p}<0.05$, Fig. 4b). However, only quercetin (3) $\left(\mathrm{IC}_{50}: 7.77 \pm 27.86 \mu \mathrm{M}\right)$ was found to be more active than ketotifen fumarate $\left(\mathrm{IC}_{50}: 16.38 \pm 0.10 \mu \mathrm{M}\right)$ in inhibiting histamine release.

Table 3 Cell viability of crude extracts on RBL-2H3 cells

\begin{tabular}{|c|c|c|c|}
\hline & $7.81 \mu \mathrm{g} / \mathrm{mL}$ & $\begin{array}{l}15.63 \\
\mu \mathrm{g} / \mathrm{mL}\end{array}$ & $\begin{array}{l}31.25 \\
\mu \mathrm{g} / \mathrm{mL}\end{array}$ \\
\hline M. oleifera leaves & $100.37 \pm 1.61$ & $101.65 \pm 4.45$ & $92.79 \pm 6.50$ \\
\hline M. oleifera seed & $96.52 \pm 5.50$ & $103.22 \pm 2.90$ & $95.07 \pm 1.77$ \\
\hline M. oleifera pod & $93.32 \pm 13.17$ & $95.72 \pm 10.01$ & $92.30 \pm 5.18$ \\
\hline Ethyl-(E)-undec-6-enoate (MOLH 1) & $94.29 \pm 3.73$ & $90.78 \pm 7.36$ & $84.30 \pm 9.38$ \\
\hline Quercetin (MOLE 1) & $93.96 \pm 6.95$ & $82.15 \pm 19.95$ & $85.66 \pm 17.00$ \\
\hline Kaempferol (MOLE 2) & $108.82 \pm 3.69$ & $100.06 \pm 9.25$ & $100.18 \pm 7.82$ \\
\hline 3,5,6-trihydroxy-2-(2,3,4,5,6-pentahydroxyphenyl)-4H-chromen-4-one (MOLE 3) & $95.36 \pm 5.55$ & $86.50 \pm 3.68$ & $83.15 \pm 6.98$ \\
\hline$\beta$-sitosterol-3-O-glucoside (MOLA 1) & $69.54 \pm 6.74$ & $64.39 \pm 6.29$ & $62.60 \pm 11.26$ \\
\hline Stigmasterol (MOPE 1) & $68.78 \pm 2.32$ & $54.39 \pm 7.15$ & $58.32 \pm 5.99$ \\
\hline Oleic acid (MOSE 1) & $82.03 \pm 3.24$ & $66.95 \pm 4.33$ & $63.63 \pm 3.45$ \\
\hline Glucomoringin (MOSA 1) & $77.87 \pm 35.88$ & $75.29 \pm 10.24$ & $58.63 \pm 24.19$ \\
\hline Ketotifen fumarate (positive control) & $112.74 \pm 22.95$ & $100.81 \pm 17.00$ & $88.00 \pm 3.13$ \\
\hline
\end{tabular}




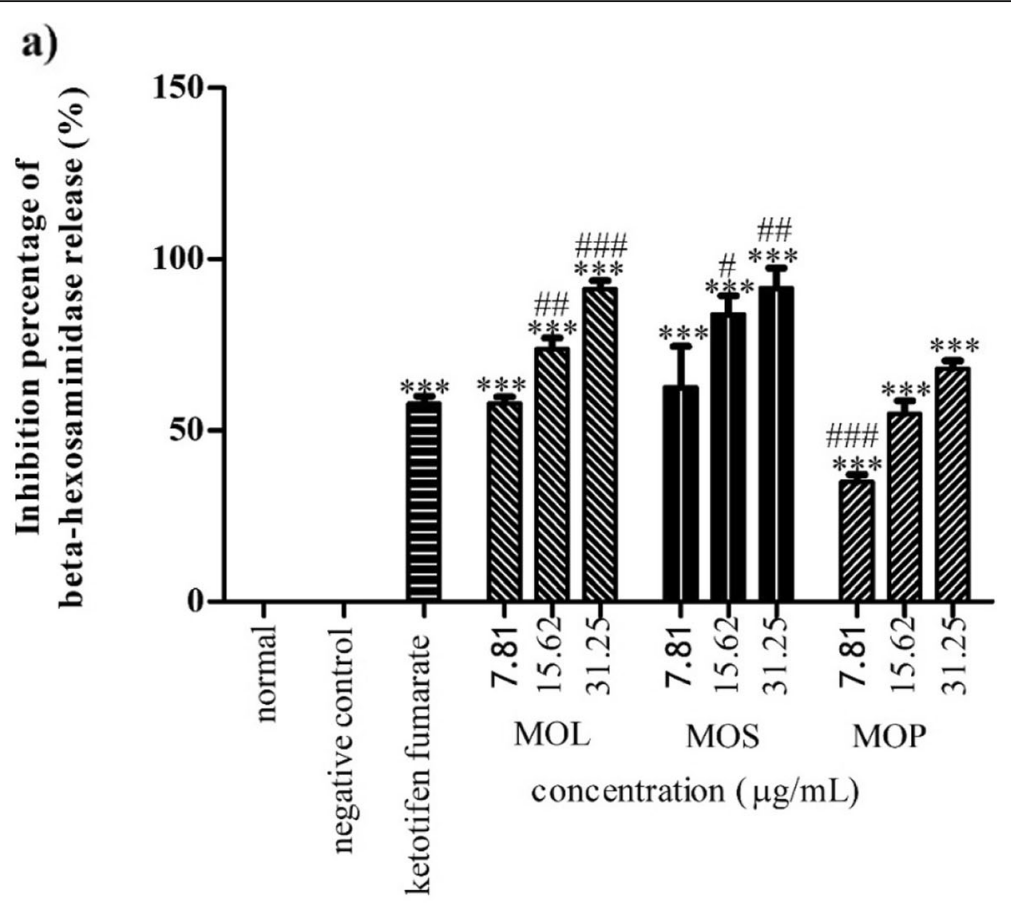

b)

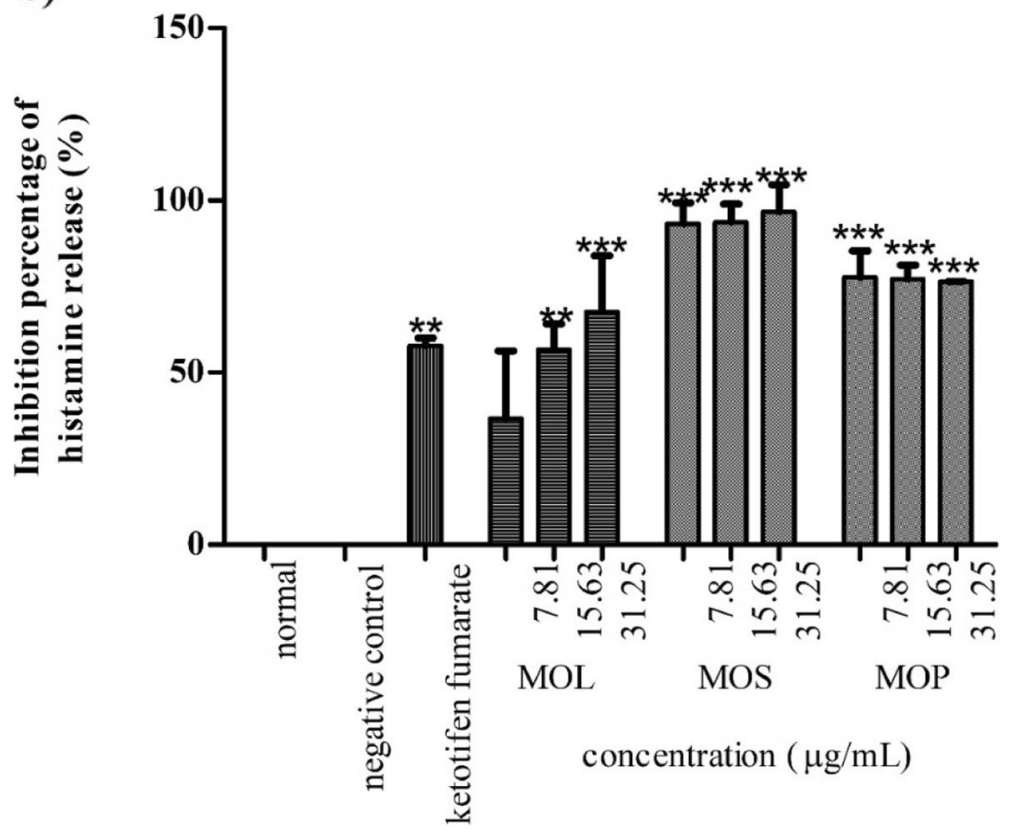

Fig. 3 Percentage inhibition of M. oleifera crude extracts on a) beta-hexosaminidase and $\mathbf{b}$ ) histamine releases. Data are presented as mean \pm SEM $(n=3)$ with significant value of ${ }^{* *} p<0.01,{ }^{* *} p<0.001$ as compared to positive control and ${ }^{\#} p<0.05,{ }^{\# \#} p<0.01,{ }^{\# \# \#} p<0.001$ as compared to ketotifen fumarate $(15.62 \mu \mathrm{g} / \mathrm{mL})$. MOL: M. oleifera leaves, MOS: M. oleifera seeds, MOP: M. oleifera pods

\section{Inhibitory effect on cytokines release}

Generally, all extracts (Fig. 5a) and the isolated compounds (Fig. 6a) inhibited IL-4 release at varying concentrations, compared with ketotifen fumarate. M. oleifera leaf and pod extracts showed higher inhibitory activity with $\mathrm{IC}_{50}$ values of $2.32 \pm 0.08$ and $2.74 \pm 0.17 \mu \mathrm{g} / \mathrm{mL}$, respectively, than ketotifen fumarate $\left(\mathrm{IC}_{50}: 3.08 \pm 0.49 \mu \mathrm{g} / \mathrm{mL}\right.$ ) (Table 5). All isolated compounds, except 3,5,6-trihydroxy-2-(2,3,4,5,6pentahydroxyphenyl)-4H-chromen-4-one (2) and glucomoringin (7), exhibited higher inhibition percentage of IL-4 release at $31.25 \mu \mathrm{g} / \mathrm{mL}$ than ketotifen fumarate (Fig. 6a). However, based on the $\mathrm{IC}_{50}$ values (Table 5), $\beta$-sitosterol-3- 


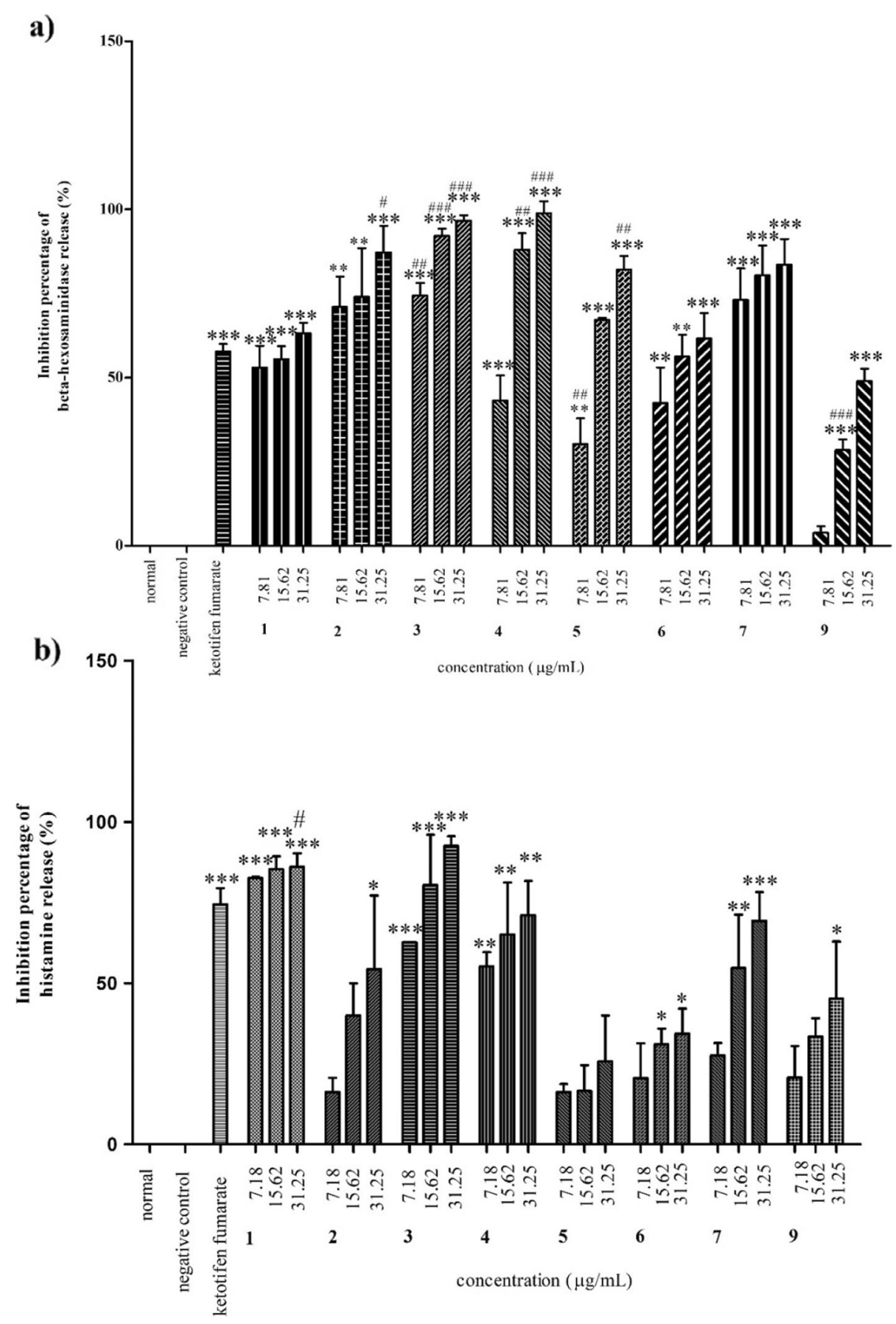

Fig. 4 Percentage inhibition of M. oleifera test compounds on a) beta-hexosaminidase and $\mathbf{b}$ ) histamine releases. Data are presented as mean \pm SEM ( $n=3)$ with significant value of ${ }^{*} p<0.05,{ }^{* *} p<0.01,{ }^{* * *} p<0.001$ as compared to positive control and and ${ }^{\#} p<0.05,{ }^{\# \#} p<0.01$, ${ }^{\# \# \#} p<0.001$ as compared to ketotifen fumarate. Ethyl-(E)-undec-6-enoate (1), 3,5,6-trihydroxy-2-(2,3,4,5,6-pentahydroxyphenyl)-4H-chromen-4-one (2), Quercetin (3), Kaempferol (4), ß-sitosterol-3-O-glucoside (5), Oleic acid (6), Glucomoringin (7), Stigmasterol (9)

O-glucoside (5) $\left(\mathrm{IC}_{50}: 7.33 \pm 1.76 \mu \mathrm{M}\right)$ and glucomoringin (7) $\left(\mathrm{IC}_{50}: 7.59 \pm 0.39 \mu \mathrm{M}\right)$ showed the most comparable inhibitory activity to ketotifen fumarate $\left(\mathrm{IC}_{50}: 7.24 \pm\right.$ $1.16 \mu \mathrm{M})$.

For the inhibitory activity of TNF- $\alpha$ release, the extracts of leaves, seeds and pods were found to be more active with $\mathrm{IC}_{50}$ values of $1.20 \pm 0.29,2.52 \pm 0.33$ and $2.52 \pm 0.15 \mu \mathrm{g} / \mathrm{mL}$, respectively, than ketotifen fumarate $\left(\mathrm{IC}_{50}: 2.91 \pm 0.33 \mu \mathrm{g} / \mathrm{mL}\right.$ ) (Table 5). Nonetheless, all the isolated compounds also showed higher percentage of inhibitory activity at concentrations of 15.62 and $31.25 \mu \mathrm{g} / \mathrm{mL}$ compared with ketotifen fumarate (Fig. 6b). 
Table $4 I_{50}$ values of inhibition towards beta-hexosaminidase and histamine release

\begin{tabular}{llr}
\hline & \multicolumn{1}{c}{ IC $_{50}$ values of inhibition } \\
\cline { 2 - 3 } & Beta-hexosaminidase & Histamine \\
\hline M. oleifera leaf extract & $7.17 \pm 1.69 \mu \mathrm{g} / \mathrm{mL}^{* *}$ & $11.66 \pm 1.26 \mu \mathrm{g} / \mathrm{mL}$ \\
M. oleifera seed extract & $10.68 \pm 0.63 \mu \mathrm{g} / \mathrm{mL}$ & $5.97 \pm 0.84 \mu \mathrm{g} / \mathrm{mL}$ \\
M. oleifera pod extract & $14.89 \pm 1.25 \mu \mathrm{g} / \mathrm{mL}$ & $7.43 \pm 1.01 \mu \mathrm{g} / \mathrm{mL}$ \\
Ethyl-(E)-undec-6-enoate (1) & $82.68 \pm 1.98 \mu \mathrm{M}$ & $82.07 \pm 13.75 \mu \mathrm{M}$ \\
3,5,6-trihydroxy-2-(2,3,4,5,6-pentahydroxyphenyl)-4H-chromen-4-one (2) & $17.70 \pm 23.29 \mu \mathrm{M}$ & $44.87 \pm 2.13 \mu \mathrm{M}$ \\
Quercetin (3) & $19.07 \pm 7.19 \mu \mathrm{M}^{*}$ & $7.77 \pm 27.86 \mu \mathrm{M}$ \\
Kaempferol (4) & $29.39 \pm 6.26 \mu \mathrm{M}$ & $46.94 \pm 10.26 \mu \mathrm{M}$ \\
B-sitosterol-3-O-glucoside (5) & - \\
Oleic acid (6) & $24.93 \pm 2.10 \mu \mathrm{M}$ & $56.05 \pm 37.11 \mu \mathrm{M}$ \\
Glucomoringin (7) & $53.76 \pm 8.95 \mu \mathrm{M}$ & $27.22 \pm 18.62 \mu \mathrm{M}$ \\
Stigmasterol (9) & $10.43 \pm 1.51 \mu \mathrm{M}^{*}$ & $38.27 \pm 24.48 \mu \mathrm{M}$ \\
Ketotifen fumarate (positive control) & $75.92 \pm 4.66 \mu \mathrm{M}$ & $6.97 \pm 0.04 \mu \mathrm{g} / \mathrm{mL}$ \\
& $15.19 \pm 1.10 \mu \mathrm{g} / \mathrm{mL}$ & $(16.38 \pm 0.10 \mu \mathrm{M})$ \\
\hline
\end{tabular}

However, glucomoringin (7) $\left(\mathrm{IC}_{50}: 3.86 \pm 8.26 \mu \mathrm{M}\right)$ and $\beta$-sitosterol-3-O-glucoside (5) $\left(\mathrm{IC}_{50}: \quad 5.26 \pm 0.00 \mu \mathrm{M}\right)$ were found to be even more active than ketotifen fumarate $\left(\mathrm{IC}_{50}: 6.85 \pm 0.77 \mu \mathrm{M}\right)$ (Table 5).

\section{Discussion}

Moringa oleifera is a commonly used plant that has high nutritional and medicinal values. However, scientific report on its anti-allergic property to support the traditional use is still inadequate. High content of flavonoids and flavanol glucosides in M. oleifera such as quercetin, astragalin, kaempferol and rutin could be associated with the anti-allergic potential of the plant [10].

From this study, nine compounds were isolated from the $M$. oleifera ethanol (80\%) extracts of various plant parts. Ethyl-(E)-2-undec-6-enoate (1), 3,5,6-trihydroxy-2-(2,3,4,5, 6-pentahydroxyphenyl)-4H-chromen-4-one (2), quercetin (3), kaempferol (4) and $\beta$-sitosterol-3-O-glucoside (5) were isolated from the leaves extract. Oleic acid (6) and glucomoringin (7) were isolated from the seeds extract; while 3, 5,6-trihydroxy-2-(2,3,4,5,6-pentahydroxyphenyl)- $4 \mathrm{H}$-chromen-4-one (2), $\beta$-sitosterol-3-O-glucoside (5), 2,3,4-trihydroxybenzaldehyde (8) and stigmasterol (9) were isolated from the pod extract. Amongst the compounds isolated, ethyl-(E)-2-undec-6-enoate (1) and 3,5,6-trihydroxy-2-(2,3, 4,5,6-pentahydroxyphenyl)-4H-chromen-4-one (2) were new compounds isolated in natural product chemistry, whereas 2,3,4-trihydroxybenzaldehyde (8) is the first to be reported of its presence in Moringaceae species.

RBL-2H3 cells derived from rat basophils were used to determine the allergic responses in vitro. Basophils have similarities with mast cells based on the composition of the granules and reactions towards allergens [35]. The mast cell degranulation was measured using betahexosaminidase and histamine as markers [36]. Upon exposure, the allergens will crosslink with the high-affinity IgE receptor to form IgE-Fc RI complex triggering the basophils to degranulate and release mediators such as beta-hexosaminidase and histamine [19]. Histamine is a well-known mediator to induce bronchoconstriction and vasodilation in an allergic reaction. However, no significant involvement of beta-hexosaminidase is reported on allergic responses [37].

Early phase of an allergic reaction occurs minutes after allergen sensitisation, releasing histamine and other mediators [19]. Whereas, late phase of the allergic reaction is recognized by the release of cytokines such as IL-13, IL-4, IL-9, IL-5, IFN- $\gamma$ and TNF- $\alpha$ after 2 to $6 \mathrm{~h}$ of sensitisation. The most pivotal cytokines in an allergic reaction are IL- 4 and TNF- $\alpha$. In the presence of IL-4, it will trigger B cell activation and the production of IgE. High amount of IgE will increase the binding site of the allergen on the mast cells, hence induce allergic reactions. TNF- $\alpha$ is responsible for the recruitment of inflammatory cells such as eosinophils, neutrophils, monocytes and macrophages to the site of allergen invasion. This will lead to inflammatory-related allergic responses.

In this study, M. oleifera leaf, seed and pod extracts exhibited an anti-allergic activity by inhibiting the early and late phases of allergic reaction. The leaves extract particularly suppressed the release of beta-hexosaminidase, IL-4 and TNF- $\alpha$ more than the positive control, ketotifen fumarate. Nevertheless, it also showed better activity in the late phase of allergic reaction (Table 5). Previous studies also found that this plant suppressed TNF- $\alpha$ level of atopic dermatitis of human keratinocyte cells [38] and LPS-mediated RAW 264.7 macrophage cells [39]. 3,5,6trihydroxy-2-(2,3,4,5,6-pentahydroxyphenyl)-4H-chromen-4-one (2), quercetin (3), kaempferol (4) and $\beta$ sitosterol-3-O-glucoside (5) isolated from the leaves 

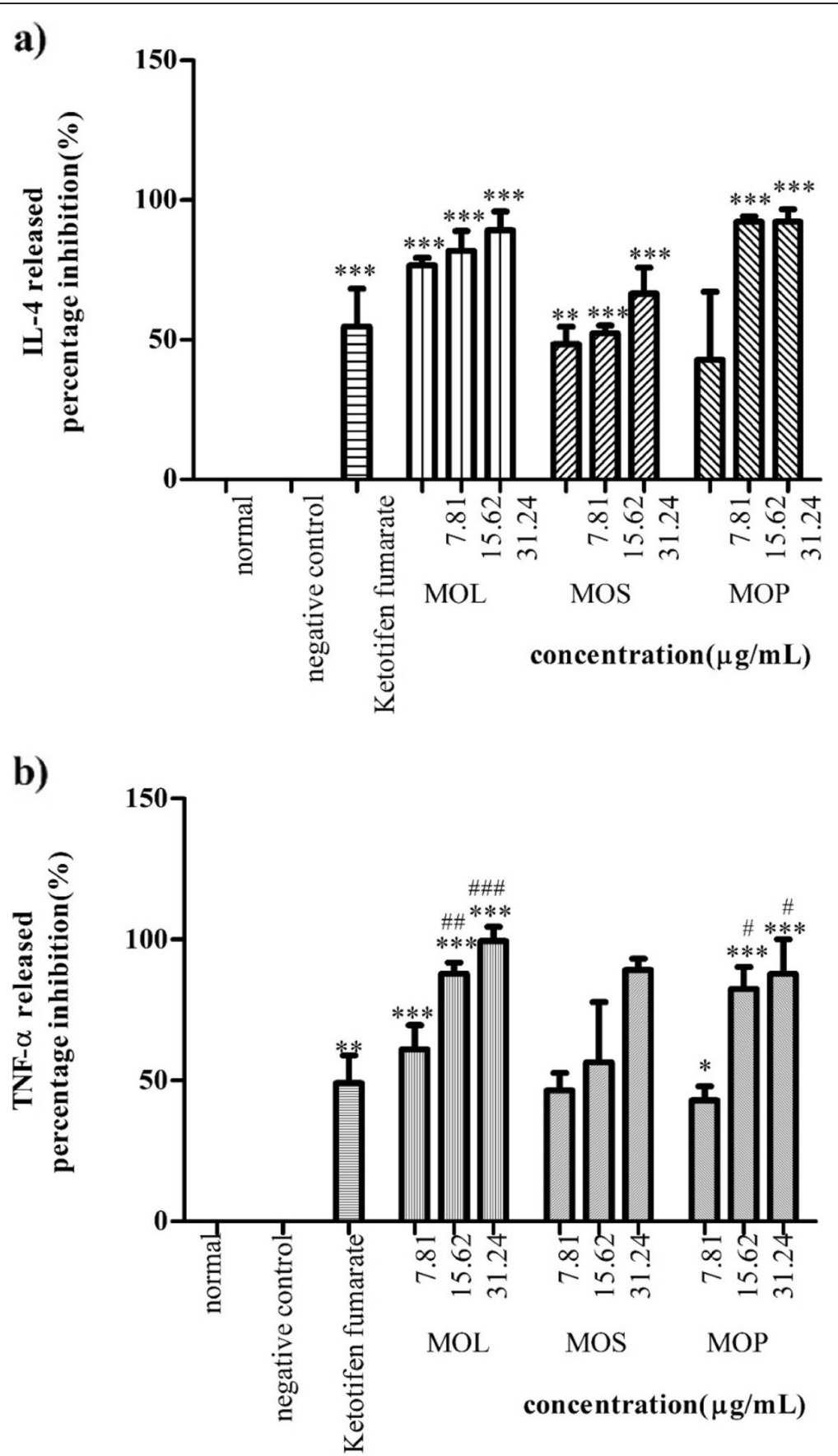

Fig. 5 Percentage inhibition of M. oleifera crude extracts on $\mathbf{a})$ IL-4 and $\mathbf{b})$ TNF-a releases. Data are presented as mean \pm SEM $(n=3)$ with significant value of ${ }^{*} p<0.05,{ }^{* *} p<0.01,{ }^{* * *} p<0.001$ as compared to positive control and ${ }^{\#} p<0.05,{ }^{\# \#} p<0.01,{ }^{\# \# \#} p<0.001$ as compared to ketotifen fumarate $(15.62 \mu \mathrm{g} / \mathrm{mL})$. MOL: M. oleifera leaves, MOS: M. oleifera seeds, MOP: M. oleifera pods

extract inhibited beta-hexosaminidase more actively than ketotifen fumarate. In the early phase of allergic reaction, quercetin (3) was found to be more potent than ketotifen fumarate in inhibiting histamine release. In the late phase, 3,5,6-trihydroxy-2-(2,3,4,5,6-pentahydroxyphenyl)-4H-

chromen-4-one (2) and quercetin (3) inhibited release of TNF- $\alpha$, while $\beta$-sitosterol-3-O-glucoside (5) inhibited both
IL- 4 and TNF- $\alpha$ release more actively than ketotifen fumarate. Flavonoids were reported to have anti-allergic properties by inhibiting histamine and IL-4 release [21]. Three flavonoids isolated from the leaves extract; 3,5,6-trihydroxy-2-(2,3,4,5,6-pentahydroxyphenyl)-4H-chromen4-one (2), quercetin (3) and kaempferol (4), might be responsible for the anti-allergic property due to their ability 


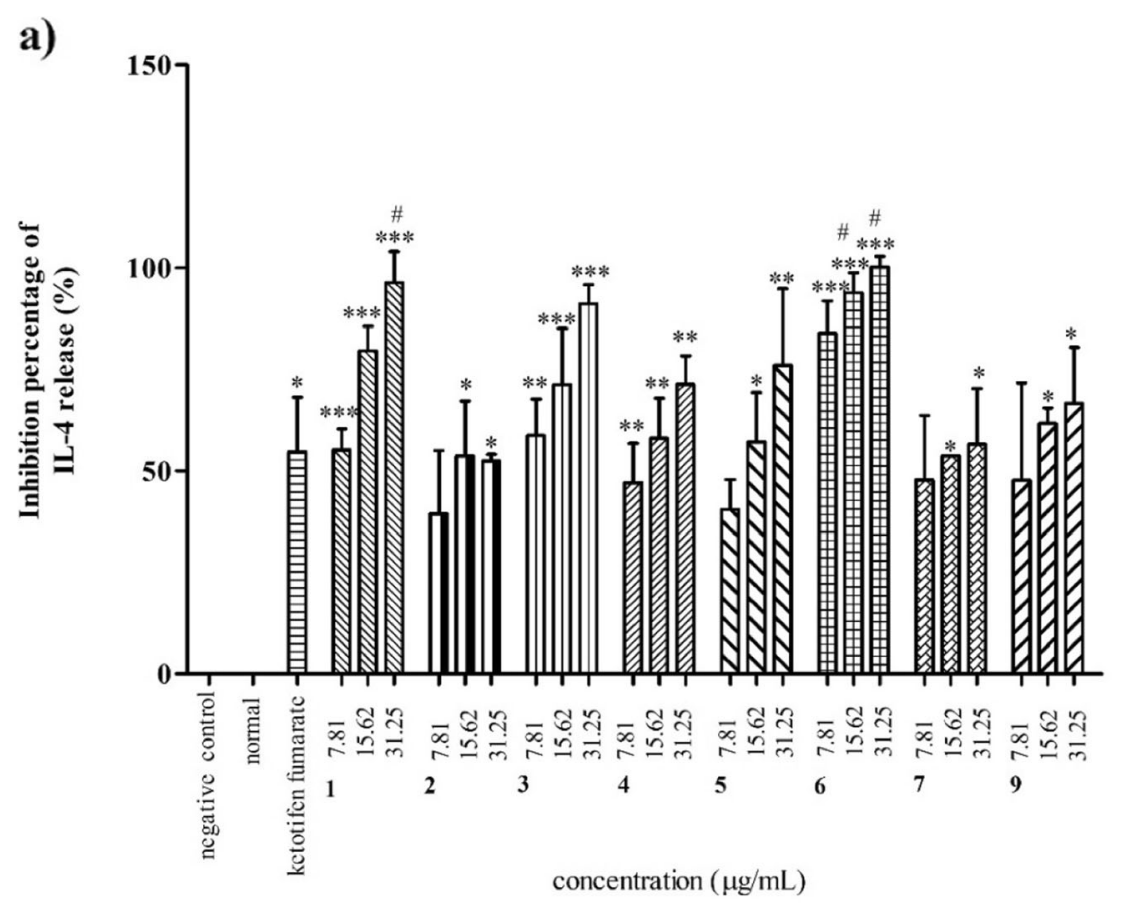

b)

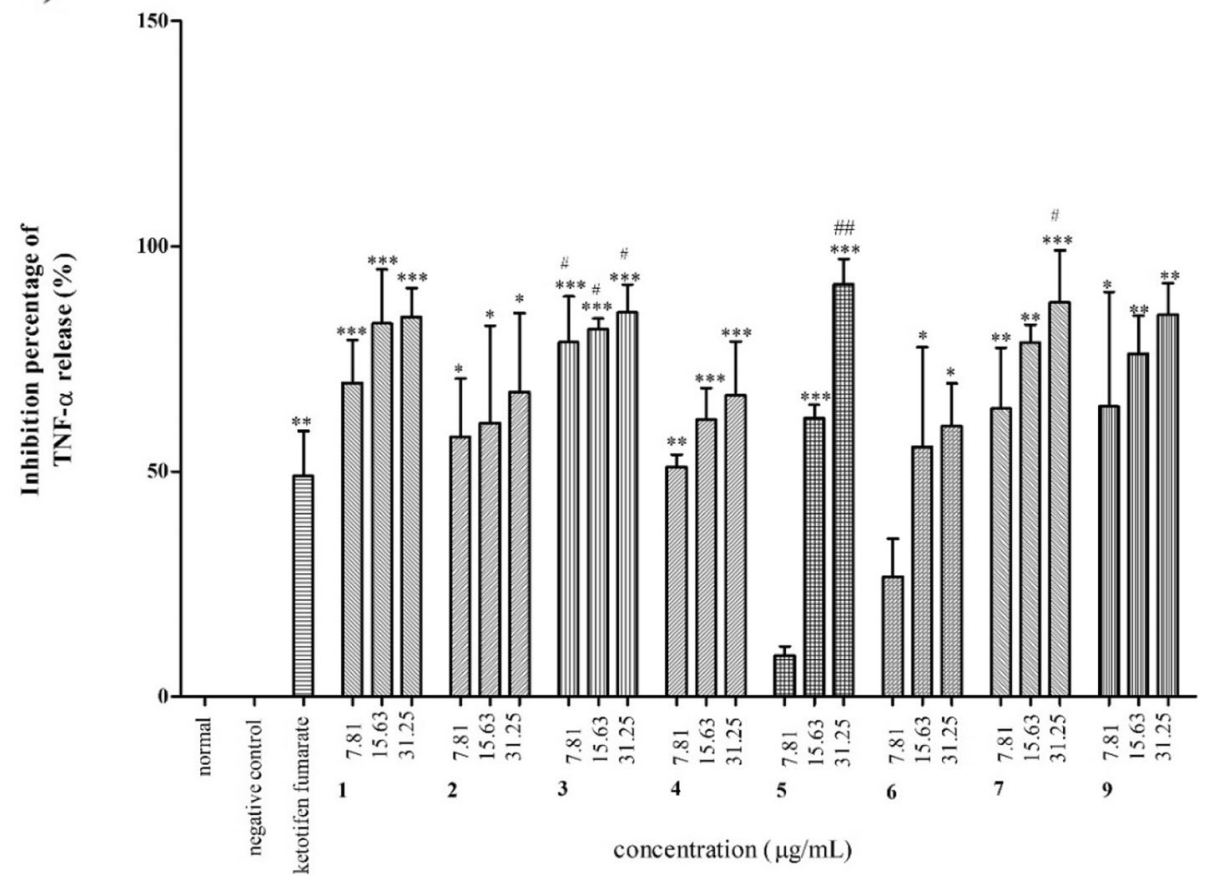

Fig. 6 Percentage inhibition of M. oleifera test compounds on a) IL-4 and $\mathbf{b})$ TNF-a releases. Data are presented as mean \pm SEM ( $n=3)$ with significant value of ${ }^{*} p<0.05,{ }^{* *} p<0.01,{ }^{* * *} p<0.001$ as compared to positive control and and ${ }^{\#} p<0.05,{ }^{\# \#} p<0.01$ as compared to ketotifen fumarate. Ethyl-(E)-undec-6-enoate (1), 3,5,6-trihydroxy-2-(2,3,4,5,6-pentahydroxyphenyl)-4H-chromen-4-one (2), Quercetin (3), Kaempferol (4), $\beta$ sitosterol-3-O-glucoside (5), Oleic acid (6), Glucomoringin (7), Stigmasterol(9)

to stabilise mast cell from degranulation and inhibit the release of IL- 4 and TNF- $\alpha$ from IgE-mediated RBL-2H3 cells. Quercetin (3) and kaempferol (4) have been reported to inhibit mast cells from degranulation by suppressing the calcium influx from extracellular medium [40, 41]. The specific pathway of inhibition was reported to be via the Syk pathway that attenuated the ERK activation and hence inhibited the release of IL-4 and TNF- $\alpha$ release [42, 43]. In 
Table $5 \mathrm{IC}_{50}$ value of inhibition towards IL-4 and TNF-a release

\begin{tabular}{llr}
\hline & \multicolumn{2}{c}{$I C_{50}$ value of inhibition } \\
\cline { 2 - 3 } & IL-4 & TNF-a \\
\hline M. oleifera leaf extract & $2.32 \pm 0.08 \mu \mathrm{g} / \mathrm{mL}$ & $1.20 \pm 0.29 \mu \mathrm{g} / \mathrm{mL}$ \\
M. oleifera seed extract & $4.28 \pm 0.05 \mu \mathrm{g} / \mathrm{mL}$ & $2.52 \pm 0.33 \mu \mathrm{g} / \mathrm{mL}$ \\
M. oleifera pod extract & $2.74 \pm 0.17 \mu \mathrm{g} / \mathrm{mL}$ & $2.52 \pm 0.15 \mu \mathrm{g} / \mathrm{mL}$ \\
Ethyl-(E)-undec-6-enoate (1) & $16.91 \pm 0.56 \mu \mathrm{M}$ & $9.90 \pm 2.31 \mu \mathrm{M}$ \\
3,5,6-trihydroxy-2-(2,3,4,5,6-pentahydroxyphenyl)-4H-chromen-4-one (2) & $6.45 \pm 0.26 \mu \mathrm{M}$ \\
Quercetin (3) & $12.17 \pm 0.13 \mu \mathrm{M}$ & $6.24 \pm 0.31 \mu \mathrm{M}$ \\
Kaempferol (4) & $10.42 \pm 0.07 \mu \mathrm{M}$ & $8.73 \pm 0.59 \mu \mathrm{M}$ \\
B-sitosterol-3-O-glucoside (5) & $14.55 \pm 3.24 \mu \mathrm{M}$ & $5.26 \pm 0.00 \mu \mathrm{M}$ \\
Oleic acid (6) & $7.33 \pm 1.76 \mu \mathrm{M}$ & $10.11 \pm 1.49 \mu \mathrm{M}$ \\
Glucomoringin (7) & $8.10 \pm 0.26 \mu \mathrm{M}$ & $3.86 \pm 8.26 \mu \mathrm{M}$ \\
Stigmasterol (9) & $7.59 \pm 0.39 \mu \mathrm{M}$ & $6.05 \pm 16.54 \mu \mathrm{M}$ \\
Ketotifen fumarate (positive control) & $10.99 \pm 1.57 \mu \mathrm{M}$ & $2.91 \pm 0.33 \mu \mathrm{g} / \mathrm{mL}$ \\
& $3.08 \pm 0.49 \mu \mathrm{g} / \mathrm{mL}$ & $(6.85 \pm 0.77 \mu \mathrm{M})$ \\
\hline
\end{tabular}

addition, quercetin (3) and kaempferol (4) also inhibited PLCY and PKC pathways of the IgE-mediated allergic reaction by reducing the expression of 5-lipoxygenase, cyclooxygenase- 2 and the production of leukotriene $\mathrm{B}_{4}$ and prostaglandin $E_{2}$ [43]. An in-vivo study showed that quercetin (3) and kaempferol (4) reduced mast-cell count of passive cutaneous anaphylaxis in mice [43]. From a structural activity relationship study, higher number of hydroxyls on ring $\mathrm{B}$ of flavanol was found to increase the inhibitory activity of histamine release in RBL-2H3 cells [24]. Quercetin (3) with two hydroxyl groups (3'4'-trihydroxy) at the flavanol ring $B$ has higher activity than kaempferol (4) with one hydroxyl group (4'-hydroxy group). In contrast, the current study proposed that flavanol with saturated hydroxy group on ring B of 3,5,6-trihydroxy-2-(2,3,4,5,6-pentahydroxyphenyl)-4H-chromen4-one (2) decreased the inhibitory activity of the compound.

The findings from this study showed that the extract of $M$. oleifera pods had higher inhibitory activity against beta-hexosaminidase and at the late phase of allergic reaction than ketotifen fumarate. The activity could be associated with its isolated compounds; 3,5,6-trihydroxy-2(2,3,4,5,6-pentahydroxyphenyl)-4H-chromen-4-one (2), $\beta$-sitosterol-3-O-glucoside (5) and stigmasterol (9). Stigmasterol (9) only inhibited TNF- $\alpha$ release in RBL-2H3 cells more significantly than ketotifen fumarate. This is supported by the fact that stigmasterol (9) did not inhibit beta-hexosaminidase release from A23187-induced RBL-2H3 cells [44]. However, the compound was found to inhibit scratching and mast cell trafficking in compound 48/80-induced ICR mice [45]. It also decreased TNF- $\alpha$ concentration, ear skin oedema and neutrophil count of Wistar rats induced by 12-O-tetradecanoylphorbol-13-acetate (TPA). With an addition of a sugar moeity on the sterol, $\beta$-sitosterol-3-O-glucoside (5) inhibited beta-hexosaminidase, IL- 4 and TNF- $\alpha$ release but did not show any significant activity on histamine release. $\beta$-sitosterol-3-O-glucoside (5) might directly inhibit beta-hexosaminidase activity instead of inhibiting mast cell degranulation. In previous studies, $\beta$-sitosterol3-O-glucoside (5) showed only $7.0 \%$ reduction of betahexosaminidase release from A23187-induced RBL-2H3 cells [44] and reduced inflammation of xylene-induced oedema in mice [46].

From this study, the $M$. oleifera seeds extract inhibited the release of beta-hexosaminidase, histamine and TNF$\alpha$ more actively than ketotifen fumarate. It could be attributed to the presence of the isolated compound, glucomoringin (7). To the best of the authors' knowledge, this is the first report of glucomoringin (7) and its effect on mast cell stabilising activity and its potential use in inhibiting the late phase of allergic response.

Long chain-containing chemical structure as seen in ethyl-(E)-undec-6-enoate (1) and oleic acid (6) exhibited the weakest mast cell stabilizing activity. Oleic acid (6) was reported to weakly inhibit histamine and betahexosaminidase release by antigen- and A23187-induced RBL-2H3 cells [47, 48]. In addition, oleic acid only slightly increased intracellular $\mathrm{Ca}^{2+}$ that induced cell degranulation [49]. In an in vivo study, peanuts containing high oleic acid was also found to be less allergenic than normal peanuts [50].

\section{Conclusion}

The leaves extract exhibited the highest inhibition against the release of beta-hexosaminidase, IL- 4 and TNF- $\alpha$, while the seed extract inhibited the histamine release the most. Further study revealed that isolated compound such as glucomoringin (7) displayed the highest inhibitory activity on beta-hexosaminidase and TNF- $\alpha$ release. Meanwhile, 
quercetin (3) was the most potent against histamine release inhibition while, $\beta$-sitosterol-3-O-glucoside (5) exhibited the highest inhibition on IL-4 release. Overall, this study suggested the anti-allergic property of ethanol (80\%) extract of $M$. oleifera leaves, seeds and pods, as well as the isolated compounds by stabilising mast cell from degranulation and inhibiting the early and late phases of allergic reaction in anti-DNP IgE sensitised RBL-2H3 cells induced by DNP-BSA. Two new compounds; ethyl- $(E)-2-$ undec-6-enoate (1) and 3,5,6-trihydroxy-2-(2,3,4,5,6-pentahydroxyphenyl)- $4 H$-chromen-4-one (2), were isolated from the leaves extract. However, only the latter compound was active against the beta-hexosaminidase and TNF- $\alpha$ release.

\section{Acknowledgements}

The authors would like to thank the Center for Research and Instrumentation (CRIM), Universiti Kebangsaan Malaysia for performing the NMR and ESIMS analyses, and staff of Faculty of Pharmacy, Universiti Kebangsaan Malaysia for the technical assistance given throughout the study.

\section{Authors' contributions}

$\mathrm{KH}, \mathrm{EK}, \mathrm{MJ}, \mathrm{JAJ}$ and LKW designed the study and revised the manuscript. NZAR performed the study, conducted data collection and prepared the manuscript. All the authors have read and approved the manuscript.

\section{Funding}

The study was funded by the Ministry of Agriculture and Agro-Based Industry, Malaysia with a grant number of NH1015D074. The funding body did not contribute to the design of the study and collection, analysis, interpretation of data and in writing the manuscript.

\section{Availability of data and materials}

All-important data regarding the study is included in this published article and any supplementary data is available from the corresponding author upon request.

\section{Ethics approval and consent to participate}

Not applicable.

\section{Consent for publication}

Not applicable.

\section{Competing interests}

The authors declared that there is no conflict of interest regarding the publication of this research paper.

Received: 16 October 2018 Accepted: 27 November 2019

Published online: 11 December 2019

\section{References}

1. Fahey JW. Moringa oleifera: A Review of the Medical Evidence for Its Nutritional, Therapeutic, and Prophylactic Properties. Part 1. Trees for Life. 2005;1.

2. Leone A, Spada A, Battezzati A, Schiraldi A, Aristil J, Bertoli S. Moringa oleifera seeds and oil: characteristics and uses for human health. Int J Mol Sci. 2016;17

3. Mahmood KT, Mugal T. Haq IU. Natl Gift- Rev J Pharm Sci Res. 2010;2:775-81.

4. Hossain MK, Sturm B, Quadt A, Hensel O. A Sustainable Natural Resource (Moringa oleifera) in Tropical and Subtropical Areas: An Intensive Literature Review. International Research on Food Security, Natural Resource Management and Rural Development; Bonn, Germany 2017.

5. Csurhes S, Navie S. Invasive plant risk assessment: Moringa oleifera. In: Queensland DoAaFB, editor. Australia: State of Queensland; 2010.

6. Mathur BS. Moringa Book. St. Louis, MI: Trees for Life International; 2005.

7. Sanchez-Machado DI, Nunez-Gastelum JA, Reyes-Moreno C, Ramirez-Wong B, Lopez-Cervantes J. Nutritional quality of edible parts of Moringa oleifera. Food Anal Methods. 2010;3:175-80.
8. Leone A, Fiorillo G, Criscuoli F, Ravasenghi S, Santagostini L, Fico G, et al. Nutritional characterization and phenolic profiling of Moringa oleifera leaves grown in Chad. Sahrawi Refugee Camps, and Haiti International Journal of Molecular Sciences. 2015;16:18923-37.

9. Thurber MD, Fahey JW. Adoption of Moringa oleifera to combat undernutrition viewed through the lens of the "diffusion of innovations" theory. Ecol Food Nutr. 2009;48:212-25.

10. Abd Rani NZ, Husain K, Kumolosasi E. Moringa genus: a review of phytochemistry and pharmacology. Frontier Pharmacology. 2018;9:26.

11. Walter A, Samuel W, Peter A, Jospeh O. Antibacterial activity of Moringa oleifera and Moringa stenopetala methanol and $\mathrm{n}$-hexane seed extracts on bacteria implicated in waterborne diseases. Afr J Microbiol Res. 2011;5:153-7.

12. Elgamily H, Moussa A, Elboraey A, El-Sayed H, Al-Moghazy M, Abdalla A. Microbiological assessment of Moringa oleifera extracts and its incorporation in novel dental remedies against some oral pathogens. Open Access Macedonian Journal of Medical Sciences. 2016;4:585-90.

13. Rahman MM, Rahman MM, Akhter S, Jamal MA, Pandeya DR, Haque MA. Control of coliform bacteria detected from diarrhea associated patients by extracts of Moringa oleifera. Nepal Medical College journal. 2010;12.

14. Chuang PH, Lee CW, Chou JY, Murugan M, Shieh BJ, Chen HM. Anti-fungal activity of crude extracts and essential oil of Moringa oleifera lam. Bioresour Technol. 2007;98:232-6.

15. Galuppo M, Giacoppo S, De Nicola GR, lori R, Navarra M, Lombardo GE. Antiinflammatory activity of glucomoringin isothiocyanate in a mouse model of experimental autoimmune encephalomyelitis. Fitoterapia. 2014;95:160-74.

16. Cheenpracha S, Park EJ, Yoshida WY, Barit C, Wall M, Pezzuto JM. Potential anti-inflammatory phenolic glycosides from the medicinal plant Moringa oleifera fruits. Bioorg Med Chem. 2010;18:6598-602.

17. Waterman C, Rojas-Silva P, Tumer TB, Kuhn P, Richard AJ, Wicks S. Isothiocyanate-rich Moringa oleifera extract reduces weigh gain, insulin resistance and hepatic gluconeogenesis in mice. Mol Nutr Food Res. 2015; 59:1013-24.

18. Chin CY, Jalil J, Ng PY, Ng SF. Development and formulation of Moringa oleifera standardised leaf extract film dressing for wound healing application. J Ethnopharmacol. 2018;212:188-99.

19. Akdis CA, Agache I. Global Atlas of Allergy: European Academy of Allergy and Clinical Immunology; 2014.

20. Chopra RN, Chopra IC, Handa KL, Kapur ID. Chopra's indigenous drugs of India. UN Dhur and Sons: Calcutta, India; 1938.

21. Kawai M, Hirano T, Higa S, Arimitsu J, Maruta M, Kuwahara Y, et al. Flavanoids and related compounds as anti-allergic substances. Allergol Int. 2007;56:113-23.

22. Pinho BR, Sousa C, Valentao P, Oliveira JMA, Andrade PB. Modulation of basophils' degranulation and AllergyRelated enzymes by monomeric and Dimeric Naphthoquinones. PLoS One. 2014;9:1-10.

23. Shahari MS, Husain K, Kumolosasi E, Rajab NF. Histamine and BetaHexosaminidase inhibitory effects of crude alkaloid from Kopsia arborea Blume in RBL-2H3 cell lines. Nat Prod: Ind J. 2017;13.

24. Mastuda H, Morikawa T, Ueda K, Managi H, Yoshikawa M. Structural requirements of flavonoids for inhibition of antigen-induced degranulation, TNF-a and IL-4 production from RBL-2H3 cells. Bioorg Med Chem. 2002;10:3123-8.

25. Itoh T, Ohguchi K, linuma M, Nozawa Y, Akao Y. Inhibitory effect of xanthones isolated from the pericarp of Garcinia mangostana $\mathrm{L}$. on rat basophilic leukemia RBL-2H3 cell degranulation. Bioorg Med Chem. 2008;16:4500-8.

26. Husain K, Zakaria SM, Lajis NH, Shaari K, Ismail IS, Israf DA, et al. Novel. sesquiterpene and copyrine alkaloids from Anaxagorea javanica Blume. Phytochem Lett. 2012;5:788-02.

27. Cornelius MTF, de Carvalho MG, da Silva TMS, Alves CCF, Siston APN, Alves KZ, et al. Other Chemical Constituents Isolated from Solanum crinitum Lam. (Solanaceae). J Braz Chem Soc. 2010;21:2211-9.

28. Wahab A, Tahira, Begum S, Ayub A, Mahmood I, Mahmood T, et al. Luteolin and kaempferol from Cassia alata, antimicrobial and antioxidant activity of its methanolic extracts. FUUAST Journal Biology. 2014;4:1-5.

29. Mouffok S, Haba H, Lavaud C, Long C, Benkhaled M. Chemical constituents of Centaurea omphalotricha Coss. \& Durieu ex Batt. \& Trab. Rec Nat Prod. 2012;6:292-5.

30. Abe M, Ito Y, Suzuki A, Onoue S, Noguchi H, Yamada S. Isolation and pharmacological characterization of fatty acids from saw palmetto extract. Anal Sci. 2009;25:553-7.

31. de Graaf RM, Krosse S, Swolfs AE, te Brinke E, Prill N, Leimu R, et al. Isolation and identification of 4-a-rhamnosyloxy benzyl glucosinolate in Noccaea caerulescens showing intraspecific variation. Phytochemistry. 2015;1 10:166-71. 
32. Mulabagal V, Alexander-Lindo RL, Dewitt DL, Nair MG. Health-beneficial phenolic aldehyde in Antigonon leptopus tea. Evid Based Complement Alternat Med. 2011;2011:6.

33. Mawa S, Jantan I, K H Isolation of Terpenoids from the Stem of Ficus Griff and their Effects on Reactive Oxygen Species Production and Chemotactic Activity of Neutrophils Molecules 2016;21:14.

34. Husain K, Jamal JA, Jalil J. Phytochemical study of Cananga odorata Hook, F. \& Thoms (Annonaceae). Int J Pharm Pharm Sci. 2012;4:465-7.

35. Miyake K, Karasuyama H. Emerging roles of basophils in allergic inflammation. Allergol Int. 2017;66:382-91.

36. Tewtrakul S, Itharat A. Anti-allergic substances from the rhizomes of Dioscorea membranacea. Bioorg Med Chem. 2006;14:8707-11.

37. Fukuishi N, Murakami S, Ohno A, Yamanaka N, Matsui N, Fukutsuji K, et al. Does $\beta$-hexosaminidase function only as a degranulation indicator in mast cells? The primary role of $\beta$-hexosaminidase in mast cell granules. J Immunol. 2014;193:1886-94.

38. Choi EJ, Debnath T, Tang Y, Ryu YB, Moon SH, Kim EK. Topical application of Moringa oleifera leaf extract ameliorates experimentally induced atopic dermatitis by the regulation of Th1/Th2/Th17 balance. Biomed Pharmacother. 2016;84:870-7.

39. Muangnoi $C$, Chingsuwanrote $P$, Praengamthanachoti $P$, Svasti $S$, Tuntipopipat S. Moringa oleifera pod inhibits inflammatory mediator production by lipopolysaccharide-stimulated RAW 264.7 murine macrophage cell lines. Inflamm. 2012;35:445-55.

40. Itoh T, Ninomiya M, Yasuda M, Koshikawa K, Deyashiki Y, Nozawa Y, et al. Inhibitory effects of flavonoids isolated from Fragaria ananassa Duch on lgEmediated degranulation in rat basophilic leukemia RBL-2H3. Bioorg Med Chem. 2009:17:5374-9.

41. Mlcek J, Jurikova T, Skrovaknova S, Sochor J. Quercetin and its anti-allergic immune response. Mol. 2016;21.

42. Lee EJ, Ji GE, Sung MK. Quercetin and kaempferol suppress immunoglobulin E-mediated allergic inflammation in RBL-2H3 and Caco-2 cells. Inflamm Res. 2010:59:847-54.

43. Kim M, Lim SJ, Kang SW, Um BH, Nho CW. Aceriphyllum rossii extract and its active compounds, Quercetin and Kaempferol inhibit lgE-mediated mast cell activation and passive cutaneous anaphylaxis. J Agric Food Chem. 2014 62:3750-8.

44. Thabet AA, Youssef FS, Korinek M, Chang FR, Wu YC, Chen BH, et al. Study of the anti-allergic and anti-inflammatory activity of Brachychiton rupestris and Brachychiton discolor leaves (Malvaceae) using in vitro models. BMC Complement Altern Med. 2018;18.

45. Antwi AO, Obiri DD, Osafo N, Essel LB, Forkuo AD, Atobiga C. Stigmasterol alleviates cutaneous allergic responses in rodents. Biomed Res Int. 2018; 2018:1-13.

46. Huang LJ, Gao WY, Li X, Zhao WS, Huang LQ, Liu CX. Evaluation of the in Vivo anti-inflammatory effects of extracts from Pyrus bretschneideri Rehd. J Agric Food Chem. 2010;58:8983-7.

47. Teshima R, Amano F, Nakamura R, Tanaka Y, Sawada J. Effects of polyunsaturated fatty acids on calcium response and degranulation from RBL-2H3 cells. Int Immunopharmacol. 2007:7:205-10.

48. Korinek M, Tsai Y-H, El-Shazly M, Lai K-H, Backlund A, Wu S-F, et al. Antiallergic Hydroxy fatty acids from Typhonium blumei explored through ChemGPS-NP. Front Pharmacol. 2017;8.

49. Kim MC, Kim MG, Jo YS, Song HS, Eom TI, Sim SS. Effects of C18 fatty acids on intracellular $\mathrm{Ca} 2+$ mobilization and histamine release in RBL-2H3 cells. Korean J Physiol Pharmacol. 2014;18:241-7.

50. Nguyen TTH, Sakurai H, Miyahara M, Yoshihashi T, Uematsu T, Yamaki T, et al. Comparative study on allergenic properties of high-oleic and conventional peanuts. Pol J Food Nutr Sci. 2003;12:88-95.

\section{Publisher's Note}

Springer Nature remains neutral with regard to jurisdictional claims in published maps and institutional affiliations.

Ready to submit your research? Choose BMC and benefit from:

- fast, convenient online submission

- thorough peer review by experienced researchers in your field

- rapid publication on acceptance

- support for research data, including large and complex data types

- gold Open Access which fosters wider collaboration and increased citations

- maximum visibility for your research: over $100 \mathrm{M}$ website views per year

At BMC, research is always in progress.

Learn more biomedcentral.com/submissions 